\title{
Determination of glycoside hydrolase specificities during hydrolysis of plant cell walls using glycome profiling
}

Johnnie A. Walker ${ }^{1,2 \dagger}$, Sivakumar Pattathil ${ }^{3,4+}$, Lai F. Bergeman 1,2, Emily T. Beebe ${ }^{1,2}$, Kai Deng ${ }^{5,6}$, Maryam Mirzai ${ }^{3,4}$, Trent R. Northen ${ }^{5,7}$, Michael G. Hahn $n^{3,4}$ and Brian G. Fox ${ }^{1,2^{*}}$

\begin{abstract}
Background: Glycoside hydrolases (GHs) are enzymes that hydrolyze polysaccharides into simple sugars. To better understand the specificity of enzyme hydrolysis within the complex matrix of polysaccharides found in the plant cell wall, we studied the reactions of individual enzymes using glycome profiling, where a comprehensive collection of cell wall glycan-directed monoclonal antibodies are used to detect polysaccharide epitopes remaining in the walls after enzyme treatment and quantitative nanostructure initiator mass spectrometry (oxime-NIMS) to determine soluble sugar products of their reactions.

Results: Single, purified enzymes from the GH5_4, GH10, and GH11 families of glycoside hydrolases hydrolyzed hemicelluloses as evidenced by the loss of specific epitopes from the glycome profiles in enzyme-treated plant biomass. The glycome profiling data were further substantiated by oxime-NIMS, which identified hexose products from hydrolysis of cellulose, and pentose-only and mixed hexose-pentose products from the hydrolysis of hemicelluloses. The GH10 enzyme proved to be reactive with the broadest diversity of xylose-backbone polysaccharide epitopes, but was incapable of reacting with glucose-backbone polysaccharides. In contrast, the GH5 and GH11 enzymes studied here showed the ability to react with both glucose- and xylose-backbone polysaccharides.
\end{abstract}

Conclusions: The identification of enzyme specificity for a wide diversity of polysaccharide structures provided by glycome profiling, and the correlated identification of soluble oligosaccharide hydrolysis products provided by oximeNIMS, offers a unique combination to understand the hydrolytic capabilities and constraints of individual enzymes as they interact with plant biomass.

Keywords: Glycoside hydrolase, Xylanase, Xyloglucanase, Glycome profiling, Nanostructure-initiator mass spectrometry, Enzyme specificity

\section{Background}

The cell walls of plants provide renewable material that can be converted to energy (biofuels) and chemicals (biocommodities). Effective deployment of biofuels can help to reduce greenhouse gas emissions [1]. Moreover, supplementation of petroleum-based energy and chemicals

\footnotetext{
*Correspondence: bgfox@biochem.wisc.edu

†Johnnie A. Walker and Sivakumar Pattathil contributed equally to this work

2 Department of Biochemistry, University of Wisconsin-Madison, Madison, WI 53706, USA

Full list of author information is available at the end of the article
}

with renewable substitutes can increase national and economic security during times of fluctuating oil price and availability. Some ideal sources of plant biomass for energy and biocommodities production include agricultural wastes (e.g., corn stover and wood) and low-input, high-yield perennial plants (e.g., switchgrass or poplar) that can potentially be grown on marginal lands [2].

Plant biomass is composed of polymers such as lignin, cellulose, hemicellulose, pectin, and other polysaccharides. In grasses like corn stover and switchgrass, lignin accounts for $10-20 \%$ of dry weight, cellulose $35-45 \%$, hemicellulose $20-40 \%$, and pectin at lower percentage 
[3-7]. The ultrastructure of plant cell walls consists of bundles of crystalline cellulose microfibrils that are noncovalently associated with the various hemicellulose polysaccharides including xyloglucans, while glucuronoarabinoxylans are thought to provide both covalent and non-covalent connections between interwoven strands of cellulose, xyloglucan, and pectin [8-15]. Connections between xylan and pectin involving cell wall proteins were also identified recently $[16,17]$. Consequently, plant biomass is a durable material that is difficult to efficiently convert into simple sugars and monomeric aromatic compounds.

This work focuses on the hemicelluloses, which include xylans, arabinoxylans, and xyloglucans. Xylans consist of a $\beta$-1,4-linked D-xylose backbone that can have a variety of substituents [18, 19]. Glucuronoarabinoxylans (heteroxylans), which are abundant in grasses, have primary glucuronyl substitutions at the $\mathrm{C}(\mathrm{O}) 2$ and/or arabinofuranosyl substitutions at $\mathrm{C}(\mathrm{O}) 3$ positions $[18,20,21]$. These primary substitutions may in turn have glucuronosyl, methyl-glucuronosyl, or feruloyl substitutions, which introduces additional variation in xylan structure and also provides opportunities for crosslinking of xylan to lignin [22-24]. Xyloglucans found in grasses have a $\beta-1,4-$ linked D-glucose backbone with a regular pattern of $\alpha-1,6$ xylose branching [25]. The branches can have galactose and/or arabinose substituents, and the galactose can also be fucosylated at $\mathrm{C}(\mathrm{O}) 2$, though the latter modification is not highly prevalent in monocot grasses [26]. Other polysaccharides in grasses include mixed-linkage $\beta$-glucans $[18,20,21]$, mannans $[27,28]$, and pectins $[9,14,29]$.

Pretreatments increase the efficiency of enzymatic hydrolysis of plant biomass. These include acidic (including organosolv and ionic liquids, IL, USA), neutral/water, and alkaline pretreatments [20,30-32]. One alkaline pretreatment, ammonia fiber expansion (AFEX), exposes plant biomass to anhydrous ammonia gas at high pressure for a short time [33]. Rapid depressurization leads to explosive expansion of the entrained ammonia gas, which physically disrupts the plant cell wall [20, 30, 34-36]. In the AFEX process, base-labile acetyl and feruloyl esters that modify and/or crosslink different polysaccharides in the cell wall are cleaved by ammonolysis to amides [3537]. Relevant to this study, glycome profiling and other studies suggest that AFEX apparently causes relatively few other changes in the covalent bonding present in the hemicellulose and cellulose fractions [32, 33, 37, 38].

In nature, many different families of glycoside hydrolases (GHs) cleave biomass polysaccharide chains into oligo- and monosaccharides [39]. Cellulases are subdivided into endo- and exo-glucanases and $\beta$-glucosidases according to their ability to hydrolyze glycosidic bonds in cellulose and $\beta$-glucan polymers internally or at chain ends, or to hydrolyze glucose from cellobiose and other short, soluble oligosaccharides, respectively. Xylanases (endo-xylanases and $\beta$-xylosidases) and mannanases (endo-mannanases and $\beta$-mannosidases) hydrolyze the glycosidic bonds of xylans and mannans, respectively, with similar functional classifications. Other accessory enzymes such as $\alpha$-glucuronidase and $\alpha$ - $L$ arabinofuranosidase are utilized to release branching substituents from the backbone chains; in these specific examples, from the backbone of xylans. Enzymes capable of these reactions fall into many different $\mathrm{GH}$ families [6, 40-43].

In this work, we compare reactions of three enzymes from Ruminiclostridium thermocellum using two AFEXpretreated grasses (corn stover and switchgrass) as the substrates. Two complementary techniques, glycome profiling and oxime-nanostructure initiator mass spectrometry (oxime-NIMS), have been used in this work. Glycome profiling uses a large and diverse suite of monoclonal antibodies (mAbs) to detect most major non-cellulosic polysaccharide epitopes present in the plant cell walls, including those in hemicelluloses [44, 45]. Glycome profiling has been used previously to reveal modifications in plant cell walls after diverse pretreatment processes [37, 46, 47], but these previous studies have not sought to explicitly link the impact of single enzymes on cell wall hydrolysis. The work reported here demonstrates that the reactions of individual GH enzymes with intact plant biomass can be studied effectively using glycome profiling. Our analyses revealed differences in the specificities of individual, purified enzymes in their reactions with AFEX-pretreated grass biomass samples.

Oxime-NIMS is another technique with great utility in studies of the hydrolysis of plant biomass [48]. This method allows quantitative, high sensitivity detection of enzyme-solubilized reducing sugars and oligosaccharides, and assignment of the proportion of hexose and pentose sugars present. Oxime-NIMS has also proven useful in elucidating differences in the behavior of different enzymes in their reactions with pure oligosaccharides and pretreated plant biomass [48-51]. Oxime-NIMS carried out in the current work revealed diagnostic differences in the soluble products released by the activities of three different purified enzymes with plant cell walls.

This combination of approaches provides new understanding of the activities of GH enzymes on the polysaccharide fraction of grass cell walls. The specificities for cell wall epitopes identified and, conversely, the specificities lacking in the three enzymes studied offer potential to guide the improvement of simple combinations of enzymes for cell wall hydrolysis. 


\section{Results}

\section{Enzymes studied}

Three enzymes from Ruminiclostridium thermocellum have been investigated. One of these, the GH5 catalytic domain of CelE (Cthe_0797), abbreviated CMX00, is a broad specificity enzyme that can hydrolyze cellulose, mannans, and xylans $[48,52]$. To increase the reactivity with insoluble polysaccharides, the CelE catalytic domain was fused to the carbohydrate binding module CBM3a from the cellulosome scaffoldin of $R$. thermocellum [48]. The fused enzyme, CMX00_3a, reacted with both the cellulose and hemicellulose fractions of pretreated plant biomass, particularly IL-treated biomass $[48,50]$.

The other two enzymes studied here are xylanases: XynY (Cthe_0912) and XynA (Cthe_2972) [53, 54]. XynY, containing a GH10 catalytic domain, was more reactive with the xylan fraction of IL-treated switchgrass than CMX00_3a [48], but did not react with cellulose. In addition, XynA, a GH11 xylanase, was of interest because of possible distinctions in the enzymatic capabilities of the xylanase members of GH10 and GH11 families [42, 53, 55-58].

Figure 1 provides a schematic representation of the domain structures of the enzymes used in this study. CMX00_3a (Fig. 1) consists of the GH5 catalytic domain (codons 36-388) from $R$. thermocellum Cthe_0797 (CMX00) connected to the CBM3a domain (codons 323-523) from $R$. thermocellum scaffoldin, Cthe_3077 [48] using an interdomain linker from Cthe_3077 (codons 324-363). The molecular mass of CMX00_3a is 60,118 Da. CMX00 hydrolyzes cellulose, mannan, and xylan, and so is abbreviated CMX, with improved activity with different insoluble polysaccharides given by fusion to a CBM with appropriate binding specificity $[48,50]$.

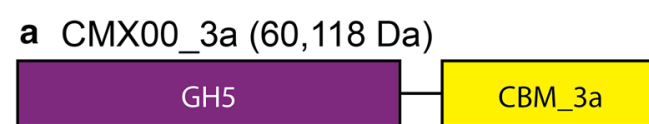

b XynY (78,573 Da)

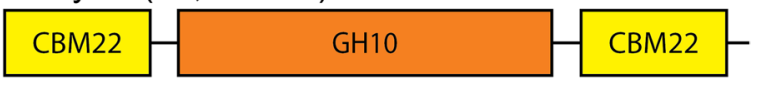

c $\operatorname{XynA}(40,317 \mathrm{Da})$

$$
\mathrm{GH} 11
$$

\section{CBM6}

Fig. 1 Schematic representations of the arrangement and relative sizes of the domains of the three enzymes studied. The $\mathrm{N}$ termini of the enzymes are on the left. Lines between domains represent linker peptides. The GH5 domain of CMX00_3a is colored purple; GH10 domain of XynY is colored orange; and the GH11 domain of XynA is colored green. Different CBM domains are colored yellow. The molecular weight of each enzyme is indicated
The structural basis of CBM3a binding to crystalline cellulose is well established [59].

The XynY construct used in this work (Fig. 1) consists of the GH10 catalytic domain and the CBM22 domains found on each side of the catalytic domain in Cthe_0912 (codons 34-720), and has a molecular mass of 78,573 Da. Relative to the natural enzyme [54], this construct removes the signal peptide from the $\mathrm{N}$-terminus, and the dockerin and esterase domains from the C-terminus. CBM22 has preference for binding to xylans [50, 60-62]. XynY has been observed to be specific for reaction with xylan-containing ( $\beta-1,4$ linked xylose) substrates ([48] and see below).

The XynA construct (Fig. 1) used here consists of the GH11 and CBM6 domains (codons 29-375), and has a molecular mass of 40,317 Da. Relative to the natural enzyme (Cthe_2972) [53], sequences for the signal peptide, dockerin, and polysaccharide deacetylase domains were removed. CBM6 is described to have binding preference for a variety of polysaccharides including $\beta-1,4$ glucan, lichenan, arabinoxylans, and xylans $[50,63]$. XynA has been reported to be specific for reaction with xylan-containing ( $\beta-1,4$ linked xylose) substrates [53], but not with xyloglucan $(\beta-1,4$ linked glucose with $\alpha-1,6$ xylose branches). This latter reactivity is demonstrated below.

\section{Enzyme reactions with pure substrates and untreated biomass}

CMX00_3a, XynY and XynA were reacted with isolated hemicellulosic polysaccharides to identify differences in specific activities and reaction specificities (Table 1; Fig. 2). We used oxime-NIMS to identify individual products from enzyme reactions with isolated hemicellulosic polysaccharides (Table 1). XynY had the highest enzyme activity followed by XynA, with a soluble product distributions dominated by pentose (X1) and pentobiose (X2). Oxime-NIMS showed that CMX00_3a had about $15-25 \%$ of the activity with oat spelt xylan relative to XynY and XynA, but the dominant products were shifted toward pentobiose (X2), pentotriose (X3), and pentotetraose (X4). All three enzymes had considerably lower activity with wheat arabinoxylan (Fig. 2), and again XynY was the most reactive, while CMX00_3a was only $1 \%$ as reactive.

Although DNS indicated both CMX00_3a and XynA released reducing sugars from tamarind xyloglucan (shown in Fig. 2), no small soluble products were detected by oxime-NIMS. Tamarind seed xyloglucan consists of a cellulosic backbone ( $\beta-1,4$ linked glucose), where, on average, 3 out of 4 glucosyl backbone residues have xylose substituents, making this a relatively heavily branched substrate [64]. The xylosyl residues 
Table 1 Soluble oligosaccharide products detected by oxime-NIMS from hydrolysis of purified polysaccharides

\begin{tabular}{|c|c|c|c|c|c|c|c|c|}
\hline & $\mathrm{P} 1^{\mathrm{a}}$ & P2 & P3 & P4 & P5 & Total & Average & Stdev \\
\hline \multicolumn{9}{|l|}{ Oat spelt xylan } \\
\hline \multirow[t]{3}{*}{ CMX00_CBM3a } & 2 & 27 & 43 & 28 & 14 & 113 & 125 & 13 \\
\hline & 2 & 28 & 49 & 31 & 14 & 124 & & \\
\hline & 2 & 29 & 48 & 40 & 19 & 139 & & \\
\hline \multirow[t]{3}{*}{ XynY } & 225 & 403 & 114 & 68 & 15 & 826 & 855 & 37 \\
\hline & 236 & 455 & 110 & 83 & 13 & 896 & & \\
\hline & 216 & 420 & 104 & 88 & 13 & 842 & & \\
\hline \multirow[t]{4}{*}{ XynA } & 88 & 277 & 2 & 5 & 118 & 488 & 468 & 25 \\
\hline & 80 & 285 & 4 & 4 & 104 & 477 & & \\
\hline & 80 & 260 & 3 & 5 & 93 & 440 & & \\
\hline & $P 1^{b}$ & P2 & P3 & $\mathrm{P} 4$ & P5 & Total & Average & Stdev \\
\hline \multicolumn{9}{|l|}{ Arabinoxylan } \\
\hline \multirow[t]{3}{*}{ CMX00_CBM3a } & 1 & 1 & 0 & 0 & 0 & 1 & 1 & 0 \\
\hline & 1 & 0 & 0 & 0 & 0 & 1 & & \\
\hline & 1 & 0 & 0 & 0 & 0 & 1 & & \\
\hline \multirow[t]{3}{*}{ XynY } & 34 & 87 & 20 & 26 & 21 & 188 & 200 & 16 \\
\hline & 39 & 102 & 24 & 29 & 24 & 219 & & \\
\hline & 36 & 90 & 20 & 25 & 22 & 193 & & \\
\hline \multirow[t]{3}{*}{ XynA } & 16 & 30 & 0 & 3 & 11 & 61 & 62 & 2 \\
\hline & 17 & 34 & 0 & 3 & 11 & 65 & & \\
\hline & 16 & 32 & 0 & 2 & 11 & 61 & & \\
\hline
\end{tabular}

Additional abbreviations used: $P 1$ pentose (i.e., likely xylose), $P 2$ pentobiose, $P 3$ pentotriose, $P 4$ pentotetraose, $P 5$ pentopentose, with $\sim 70: 15: 10$ composition of xylose:glucose:arabinose present. No mass signatures for hexose sugars were identified

a Activity reported as $\mu \mathrm{mol}$ of reducing sugar released per hour per $\mu \mathrm{mol}$ of purified enzyme determined by oxime-NIMS as described in "Methods" section

b P1 pentose (xylose and arabinose will give rise to the same mass signature in oxime-NIMS; with a 38:62 composition of arabinose and xylose and less than 1\% of glucose, galactose, and mannose present; no mass signatures for hexose sugars were identified), $P 2$ pentobiose, $P 3$ pentotriose, $P 4$ pentotetraose, $P 5$ pentopentose

can be further extended with galactosyl groups [64]. This high degree of substitution along the glucan backbone led to reducing sugar ends that could be detected by DNS, but these products were not sufficiently small to be soluble and detected by oxime-NIMS. In support of this, MALDI-MS showed CMX00_3a and XynA produced oligosaccharides with compositions of $\mathrm{Glc}_{4}-\mathrm{Xyl}_{3}$ $(m / z=1085, \mathrm{M}+\mathrm{Na}), \mathrm{Glc}_{5}-\mathrm{Xyl}_{4}(\mathrm{~m} / z=1247, \mathrm{M}+\mathrm{Na})$ and $\mathrm{Glc}_{6}-\mathrm{Xyl}_{5}(\mathrm{~m} / z=1409, \mathrm{M}+\mathrm{Na})$. These products were not observed from reactions with XynY, also consistent with the DNS results.

\section{Pretreatment-induced changes in plant biomass glycans}

AFEX pretreatment is effective on grasses [37, 65], and causes minimal changes in the hemicellulose content [66]. AFEX leads to ammonolysis of ester bonds in plant cells walls, for example, acetyl esters of xylan and feruloyl esters that crosslink arabinoxylan strands to each other and to lignin are susceptible, leading to the production of acetamide and feruloylamide [36]. As previously identified for hydrothermal pretreatment [67], most other bond types in hemicellulose are less affected by AFEX, leading to overall high-yield retention of the hemicellulose fraction [30]. This retention makes AFEX a good match for pairing with polysaccharide-epitope sensitive techniques like glycome profiling.

Figures 3 and 4 show glycome profiles of corn stover (CS) and switchgrass (SG), respectively, that were either untreated or AFEX-treated. The AFEX-treated biomasses were also incubated with different enzymes. Since enzymatic incubation was terminated by boiling the enzymebiomass mixture, we also included separate untreated and AFEX-treated controls (incubated with buffer) that were boiled along with corresponding not-boiled controls. Results from duplicate experiments in Figs. 3 and 4 are shown for each plant substrate, side by side. The amount of carbohydrate released at each extraction step (given in the bar graphs at the top of Figs. 3 and 4 and also in Table 2), and the amount of antibody binding to the extracted polysaccharides (indicated by the color intensity in the glycome profiles) are shown. The identities of the antibody classes are shown at the right, and further information on these antibodies is provided in Table S1 of the Additional file 1. Overall, across all 


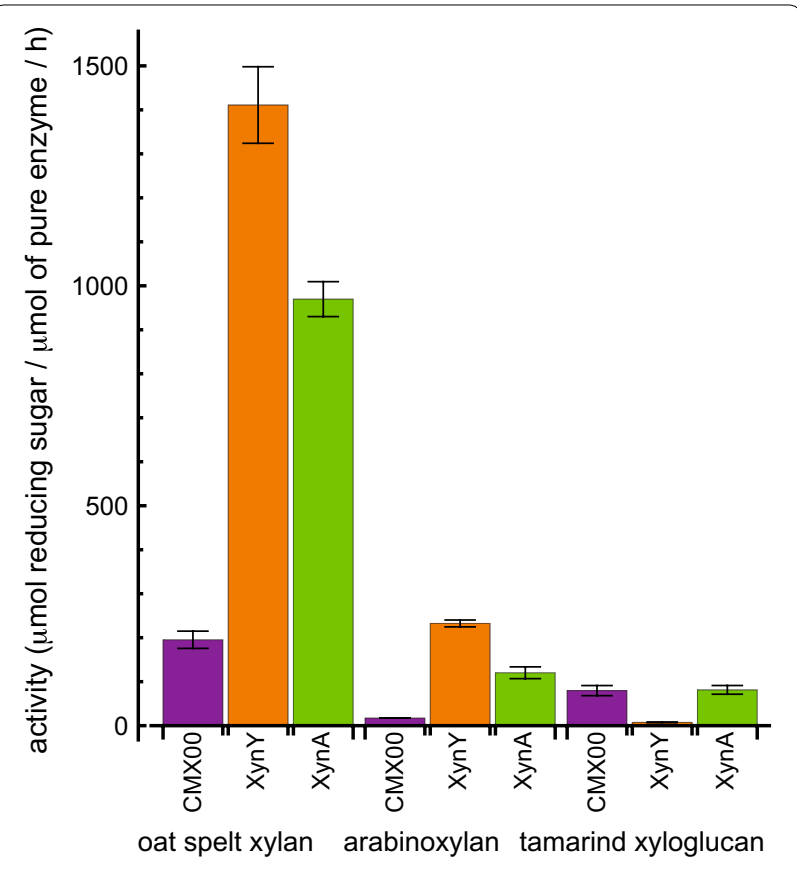

Fig. 2 Enzyme reactions with isolated polysaccharide substrates oat spelt xylan, wheat arabinoxylan, and tamarind xyloglucan. Activities detected are reported as $\mu \mathrm{mol}$ of total reducing sugar released per $\mu \mathrm{mol}$ of pure enzyme per $\mathrm{h}$ at $55^{\circ} \mathrm{C}$; results for oat spelt xylan and wheat arabinoxylan are from oxime-NIMS, results for tamarind xyloglucan are from DNS. The color bars depict the different enzymes used: CMX00_3a (purple); XynY (orange); XynA (green). Error bars represent the standard deviation of reactions carried out in triplicate

biomass samples analyzed, the replicate glycome profiles were nearly identical. Furthermore, comparison of glycome profiles of "not-boiled" versus "boiled" untreated CS and SG biomass samples showed only subtle variations suggesting minimal or insignificant alteration caused by boiling on the overall extractability of cell wall carbohydrates in untreated plant biomass. In accord with earlier studies [37, 38], AFEX pretreatment leads to an enhanced extractability of non-cellulosic cell wall polysaccharides in both CS and SG. For instance, in both AFEX-pretreated CS and SG, an enhanced abundance of epitopes from unsubstituted and substituted xylans (recognized by XYLAN-3, $-4,-5,-6$, and -7 groups of mAbs) was observed in the least harsh extracts (oxalate and carbonate). Further, enhanced extractability of xyloglucan epitopes (recognized by XG-1, XG-2, and FUC-XG groups of mAbs) was evident in the $1 \mathrm{M} \mathrm{KOH}$ extracts of AFEX-treated CS and SG samples. When boiled, AFEXtreated CS and SG samples showed slightly enhanced extractability of xylans, pectin, and mixed linkage glucan epitopes in the oxalate and/or carbonate extracts, as indicated by the enhanced abundance of epitopes detected by the XYLAN-4 through XYLAN-7 groups of mAbs, the
rhamnogalacturonan-I backbone group of $\mathrm{mAbs}$ (in both oxalate and carbonate extracts of CS and subtle increase in oxalate extract of SG) and $\beta$-GLUCAN directed antibody, BG-1.

Figure 5 shows the ELISA-based screening of the supernatant fractions from controls and enzyme treatments where the entire suite of cell wall glycan-directed mAbs used for glycome profiling was employed. These fractions contain soluble cell wall polysaccharides that were (1) endogenously present in the biomass, (2) released by the AFEX pretreatment, or (3) released and/ or modified by enzyme action. In the untreated, unboiled CS and SG supernatants, pectic arabinogalactan epitopes were present as recognized by mAbs belonging to the linseed mucilage RG-I, RG-Ib, RG-1/AG, and AG-1 through AG-4 groups. Traces of xylan epitopes were also noted in these fractions. Boiling of either of the supernatants from untreated biomass resulted in a significant loss of these signals, probably because the glycans are attached to protein backbones that precipitate and are lost as a consequence of boiling. In contrast, supernatants from AFEX-treated CS and SG had substantial presence of unsubstituted and substituted xylans as indicated by increased binding by the XYLAN-3, $-4,-5$, -6 , and -7 group antibodies, in addition to the arabinogalactan epitopes present in the controls. Xyloglucan epitopes were not detected in any of the soluble fractions analyzed.

\section{Hydrolysis of biomass by three xylan-directed enzymes}

We examined the activities of individual enzymes by incubating them with AFEX-treated CS and SG biomasses and subsequently conducting glycome profiling analyses of the unhydrolyzed insoluble residues. The presence of enzymes decreased the amount of total carbohydrate extracted in each glycome profile cell wall extract prepared from the residual solids (Table 2). Table 2 also shows that there is good mass balance when accounting for the sum of carbohydrate in the solid and soluble fractions, particularly for the CS experiment ( $\sim 10 \%$ relative difference in total). The specificities of the individual purified enzymes during biomass hydrolysis were revealed by the reduced or completely abolished binding of specific mAbs to one or more of the sequential extracts prepared from the residual unhydrolyzed solids. In general, the glycome profiles of the residual solids remaining after enzyme treatment were different for each of the three enzymes studies here, with some overlap of reactivity.

\section{Effects of CMX00_3a activity}

Compared to AFEX-treated CS and -SG not exposed to enzyme, the glycome profiles of the unhydrolyzed 


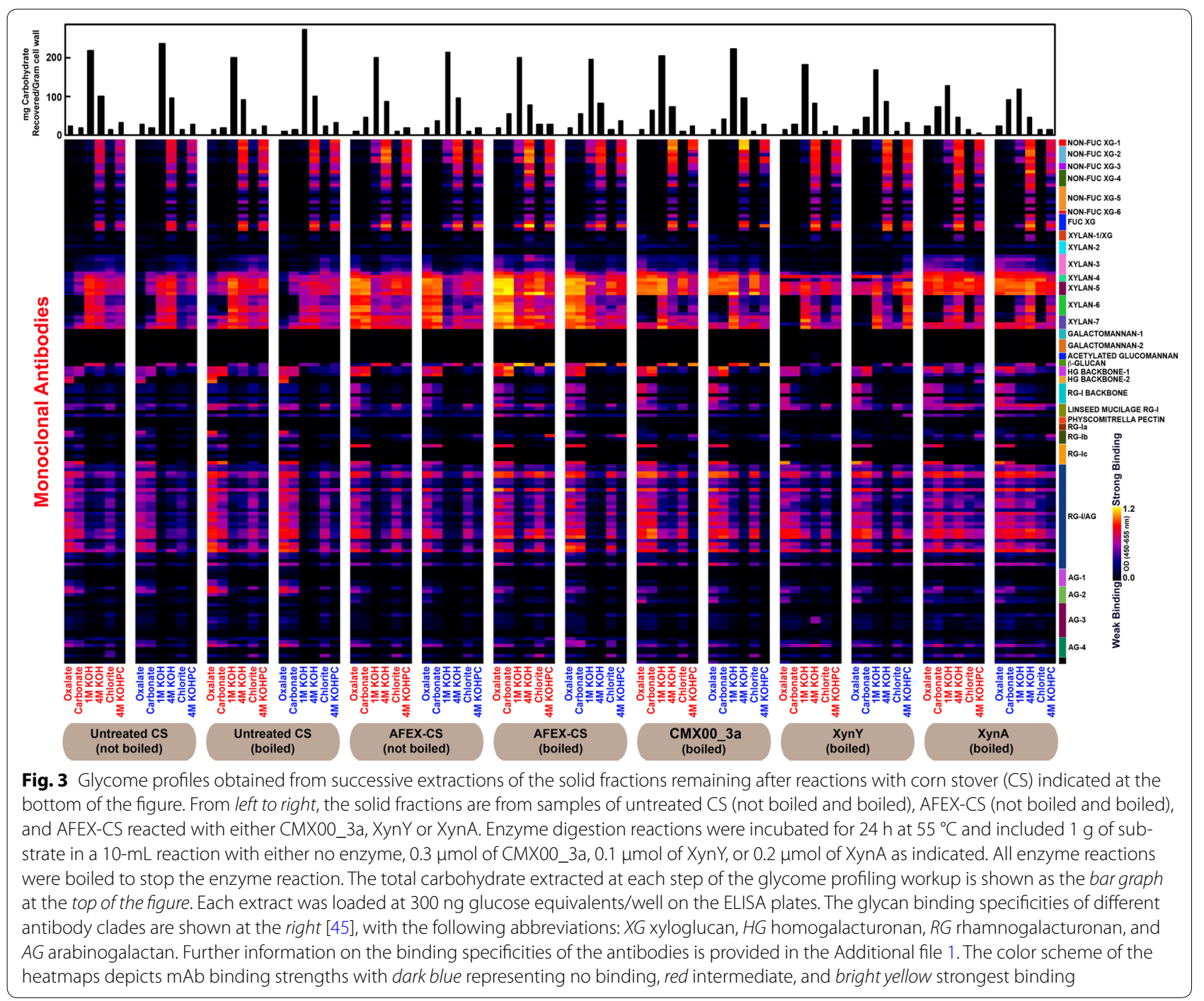

residual solids left after reaction with CMX00_3a (GH5_4) showed major changes. These changes included a near complete loss of epitopes detected by the XYLAN-6 groups of antibodies (Figs. 3,4 ) in the oxalate, carbonate, $4 \mathrm{M} \mathrm{KOH}$ and chlorite extracts. In oxalate and carbonate extracts, there was a significant loss of xylan epitopes detected by the XYLAN-7 group of mAbs with the exception of two mAbs in this group, CCRC-M152 and CCRC-M149, especially in the case of SG. There was also a reduction in the xylan epitopes recognized by the XYLAN-3 group of mAbs. In addition to the above effects of this enzyme on xylans, there was a complete loss of xyloglucan epitopes in the $1 \mathrm{M} \mathrm{KOH}$ extracts of unhydrolyzed residues from both CS and SG as indicated by the absence of binding of various NON-FUC XG mAbs and FUC-XG mAbs to these extracts.

The supernatant fractions of AFEX-CS and SG residues treated with CMX00_3a (Fig. 5) contained xylan epitopes that were detected by some xylan-directed antibodies, particularly those from the XYLAN-5 (methyl GlcA-substituted xylan) and some mAbs of the XYLAN-7 group (CCRC-M152 and CCRC-M149, homoxylan epitopes with degree of polymerization $>3$ ). However, all other xylan epitopes were absent compared to the supernatants from AFEX-treated control biomass. This suggests the presence of xylan polymers released to the supernatants by AFEX pretreatment that are resistant to hydrolysis by CMX00_3a. There was also a slight reduction in the overall abundance of various other cell wall glycan epitopes detected in the enzyme-treated supernatants, in general, relative to the supernatants from AFEX-treated biomass (e.g., RG-1/AG and AG epitopes). CMX00_3a can hydrolyze soluble oligosaccharides into shorter pieces, typically-biose and -triose fragments $[48,51]$, and these molecules are too small to be detected by the ELISA (small molecules do not adhere to the wells of the plates 


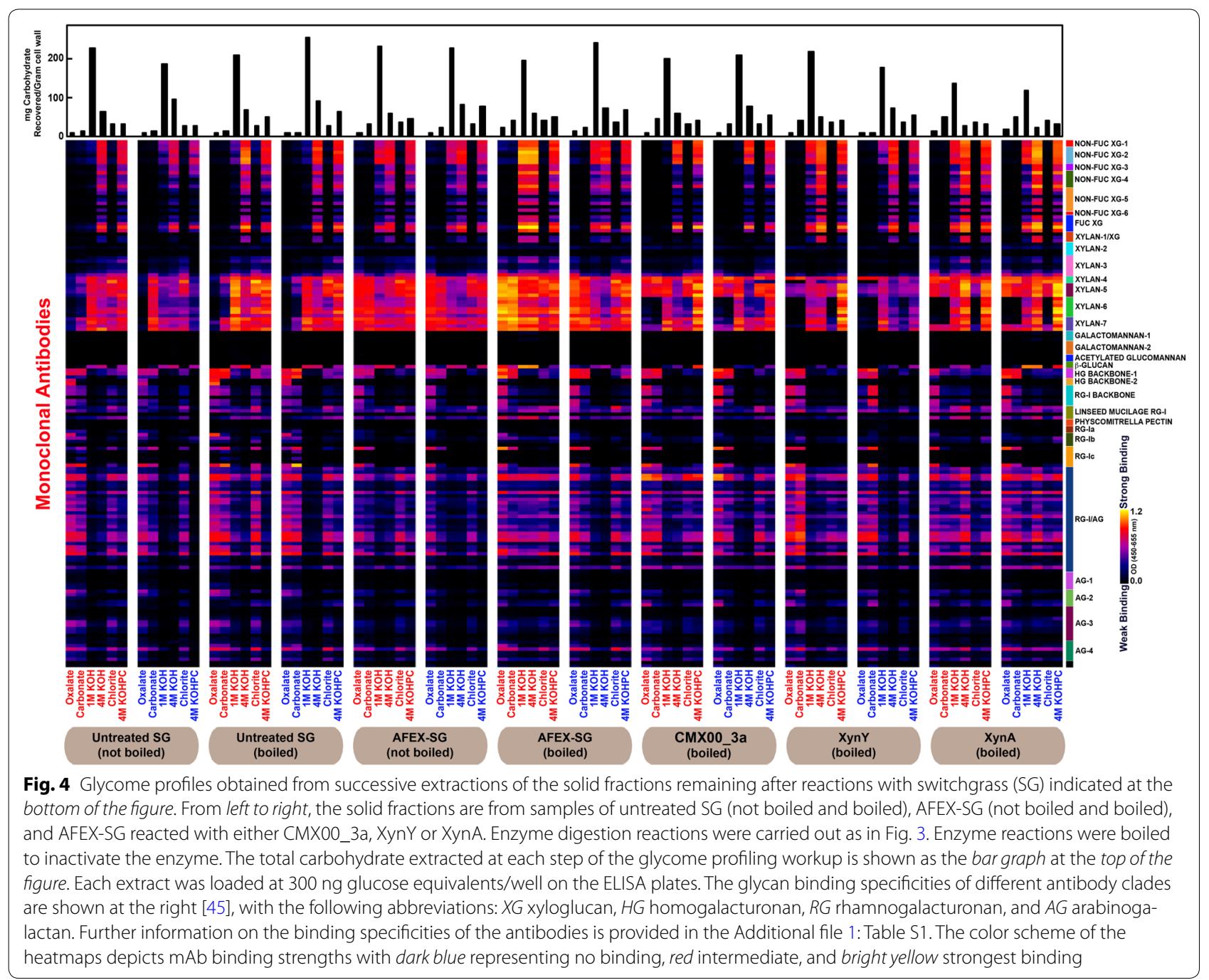

used for the assays), likely accounting for the loss in detected intensity in the soluble fraction. However, these smaller molecules were readily detected by oxime-NIMS, and those results are presented below.

\section{Effects of XynY activity}

The glycome profiles of AFEX-treated CS and SG residues treated with XynY (GH10) were distinct from the profiles obtained with CMX00_3a. Both XynY and CMX00_3a were effective in removing the xylan epitopes that are recognized by the XYLAN-6 group of mAbs from oxalate, carbonate and chlorite extracts, but CMX00_3a also removed more of the XYLAN-6 detected epitopes from the $4 \mathrm{M} \mathrm{KOH}$ extracts than did XynY. XynY completely eliminated epitopes detected by the XYLAN-3 antibodies (where the structure(s) of the epitope are unknown), and was more effective than either CMX00_3a or XynA in removing xylan epitopes that are detected by the XYLAN-7 antibodies in oxalate, carbonate, and chlorite extracts (Figs. 3, 4) suggesting enhanced reactivity of this enzyme with homoxylan in comparison with the other two. In general, there was an overall subtle decrease in the binding of XYLAN-4 (detecting arabinosylated xylan epitopes) and XYLAN-5 (methyl GlcA-substituted xylans) mAbs groups, especially against oxalate and carbonate extracts from XynY treated biomass residues of CS and SG. This suggests that XynY is potentially more active than the other two enzymes in the hydrolysis of highly substituted regions of xylans. XynY was able to remove the $1 \mathrm{M} \mathrm{KOH}$ extractable xyloglucan epitopes from AFEX-treated CS (similar to CMX00_3a), but did not fully remove these epitopes in AFEX-treated SG.

The mAb screening of supernatants (Fig. 5) supported the conclusions drawn from the glycome profiling of the residual solids after treatment with XynY. No epitopes 
Table 2 Amount of carbohydrate extracted during glycome profiling per gram of cell wall

\begin{tabular}{|c|c|c|c|c|c|c|c|}
\hline & Untreated & Boiled & AFEX & AFEX, boiled & CMX00 & XynY & XynA \\
\hline \multicolumn{8}{|l|}{ Corn stover } \\
\hline Oxalate & $2.3 \pm 0.0$ & $5.9 \pm 0.0$ & $5.0 \pm 1.1$ & $8.6 \pm 1.4$ & $4.1 \pm 0.1$ & $3.9 \pm 0.1$ & $9.6 \pm 0.9$ \\
\hline Carbonate & $3.2 \pm 0.2$ & $4.4 \pm 0.1$ & $5.1 \pm 0.5$ & $4.6 \pm 0.4$ & $4.4 \pm 0.8$ & $4.0 \pm 2.0$ & $9.3 \pm 0.6$ \\
\hline $1 \mathrm{M} \mathrm{KOH}$ & $81.4 \pm 1.5$ & $61.4 \pm 1.9$ & $48.7 \pm 1.8$ & $46.4 \pm 0.2$ & $31.9 \pm 0.9$ & $21.1 \pm 0.1$ & $20.2 \pm 1.4$ \\
\hline $4 \mathrm{M} \mathrm{KOH}$ & $44.5 \pm 2.1$ & $26.3 \pm 1.4$ & $37.4 \pm 1.8$ & $32.7 \pm 7.9$ & $21.6 \pm 2.6$ & $11.1 \pm 1.7$ & $18.7 \pm 0.2$ \\
\hline Chlorite & $7.0 \pm 1.3$ & $5.8 \pm 0.4$ & $3.6 \pm 0.4$ & $5.8 \pm 1.3$ & $2.2 \pm 0.1$ & $3.4 \pm 0.6$ & $2.9 \pm 0.1$ \\
\hline $4 \mathrm{M} \mathrm{KOHPC}$ & $9.4 \pm 0.8$ & $7.1 \pm 2.9$ & $7.8 \pm 1.0$ & $8.6 \pm 2.8$ & $4.2 \pm 0.7$ & $6.8 \pm 3.5$ & $3.2 \pm 1.1$ \\
\hline Total solid ${ }^{\mathrm{a}}$ & 147.9 & 111.0 & 107.5 & 106.8 & 68.4 & 50.3 & 63.9 \\
\hline Soluble ${ }^{b}$ & 1.5 & 1.5 & 1.5 & 1.5 & 44.6 & 65.5 & 58.9 \\
\hline Totall & 149.4 & 112.5 & 109.0 & 108.3 & 113.1 & 115.8 & 122.8 \\
\hline \multicolumn{8}{|l|}{ Switchgrass } \\
\hline Oxalate & $1.7 \pm 0.5$ & $1.8 \pm 0.7$ & $3.4 \pm 0.5$ & $5.5^{\mathrm{d}}$ & $3.2 \pm 0.0$ & $1.5 \pm 0.6$ & $6.5 \pm 1.1$ \\
\hline Carbonate & $2.5 \pm 1.2$ & $2.2 \pm 0.3$ & $3.4 \pm 0.7$ & $3.2^{d}$ & $2.6 \pm 0.1$ & $3.6 \pm 1.6$ & $4.8 \pm 0.2$ \\
\hline $1 \mathrm{M} \mathrm{KOH}$ & $58.4 \pm 13.1$ & $63.9 \pm 13.3$ & $30.6 \pm 10.0$ & $64.4^{d}$ & $33.8 \pm 13.5$ & $13.9 \pm 1.0$ & $30.6 \pm 7.6$ \\
\hline $4 \mathrm{M} \mathrm{KOH}$ & $20 . \pm 5.1$ & $37.9 \pm 9.0$ & $14.0 \pm 8.3$ & $19.8^{\mathrm{d}}$ & $13.7 \pm 2.4$ & $9.0 \pm 2.0$ & $8.8 \pm 4.2$ \\
\hline Chlorite & $7.2 \pm 0.4$ & $7.0 \pm 0.7$ & $8.3 \pm 1.3$ & $6.8^{d}$ & $5.7 \pm 0.7$ & $9.3 \pm 3.3$ & $7.1 \pm 1.1$ \\
\hline $4 \mathrm{M} \mathrm{KOHPC}$ & $10.8 \pm 12.0$ & $29.8 \pm 5.7$ & $18.5 \pm 1.8$ & $23.8^{d}$ & $15.6 \pm 1.4$ & $8.1 \pm 0.5$ & $14.2 \pm .1$ \\
\hline Total solid ${ }^{\mathrm{a}}$ & 100.5 & 142.5 & 78.2 & $123.3^{d}$ & 74.5 & 45.4 & 72.1 \\
\hline Soluble ${ }^{b}$ & 0.6 & 0.6 & 0.6 & $0.6^{d}$ & 46.3 & 69.8 & 70.0 \\
\hline Total $^{c}$ & 101.1 & 143.1 & 78.8 & $123.9^{d}$ & 120.9 & 115.2 & 142.1 \\
\hline
\end{tabular}

a Reducing sugar equivalents extracted from the solid fraction and quantified as mg quantities as reported elsewhere [46, 47]. Standard deviation calculated from two experimental replicates carried through the entire analysis method

b Reducing sugar equivalents present in the soluble fraction determined by oxime-NIMS (mg)

c Sum of solid and soluble fractions

d For boiled, AFEX-pretreated switchgrass, only single reactions were performed

recognized by the XYLAN-7 antibodies were detected in the supernatants, and the extent of binding of the XYLAN-5 antibodies was reduced in comparison with the results obtained with either CMX00_3a or XynA.

\section{Effects of XynA activity}

The glycome profiles of AFEX pretreated CS and SG residues treated with XynA (GH11) demonstrated that XynA had the narrowest substrate specificity among the three enzymes examined. Unlike the other two enzymes, XynA was not effective in removing any significant amounts of the xylan epitopes that are recognized by the XYLAN-3, -4 or -5 groups of mAbs. Further, the overall data show that XynA is not as effective as either CMX00_3a or XynY in removing the xylan epitopes detected by the XYLAN-7 antibodies (CCRC-M152 and CCRC-M149, Figs. 3, 4, 5). XynA also appeared to have limited capability to remove xyloglucan epitopes from either AFEX-treated CS or SG.

\section{Oxime-NIMS studies}

Oxime-NIMS allows quantitative detection of soluble reducing sugars released from enzyme hydrolysis of plant biomass [48]. In grasses, glucose is the dominant hexose reducing sugar, while xylose is the dominant pentose reducing sugar (see "Methods" section, enzyme reactions for the composition of corn stover and switchgrass used in this work). In the following, we distinguish between oligosaccharides containing hexose reducing sugars only (i.e., glucose, cellobiose, cellotriose, cellotetraose derived primarily from cellulose), others containing pentose reducing sugars only, and some additional oligosaccharides that contain a mixture of hexose and pentose sugars. Oxime-NIMS cannot distinguish between stereoisomers with the same mass, such as glucose and galactose, or xylose and arabinose.

Oxime-NIMS analysis of soluble products from enzyme reactions with both AFEX-CS and AFEX-SG (Tables 3, 4) showed that negligible amounts of reducing sugar were present in the supernatants either with or without AFEX treatment, while a greater than $50 \times$ increase in sugar release was observed by the addition of any of the three enzymes to the AFEX-treated material.

Figure 6 and Tables 3, 4 show that CMX00_3a released cello-oligosaccharides from the AFEX-treated biomass. At the endpoint of the reaction, CMX00_3a produced mostly cellobiose and glucose and lesser amounts of cellotriose and cellotetraose. These products are in accord with previous studies of the CMX00_3a reaction with IL-treated switchgrass, although a considerably higher yield of cellulose-derived products was observed from 


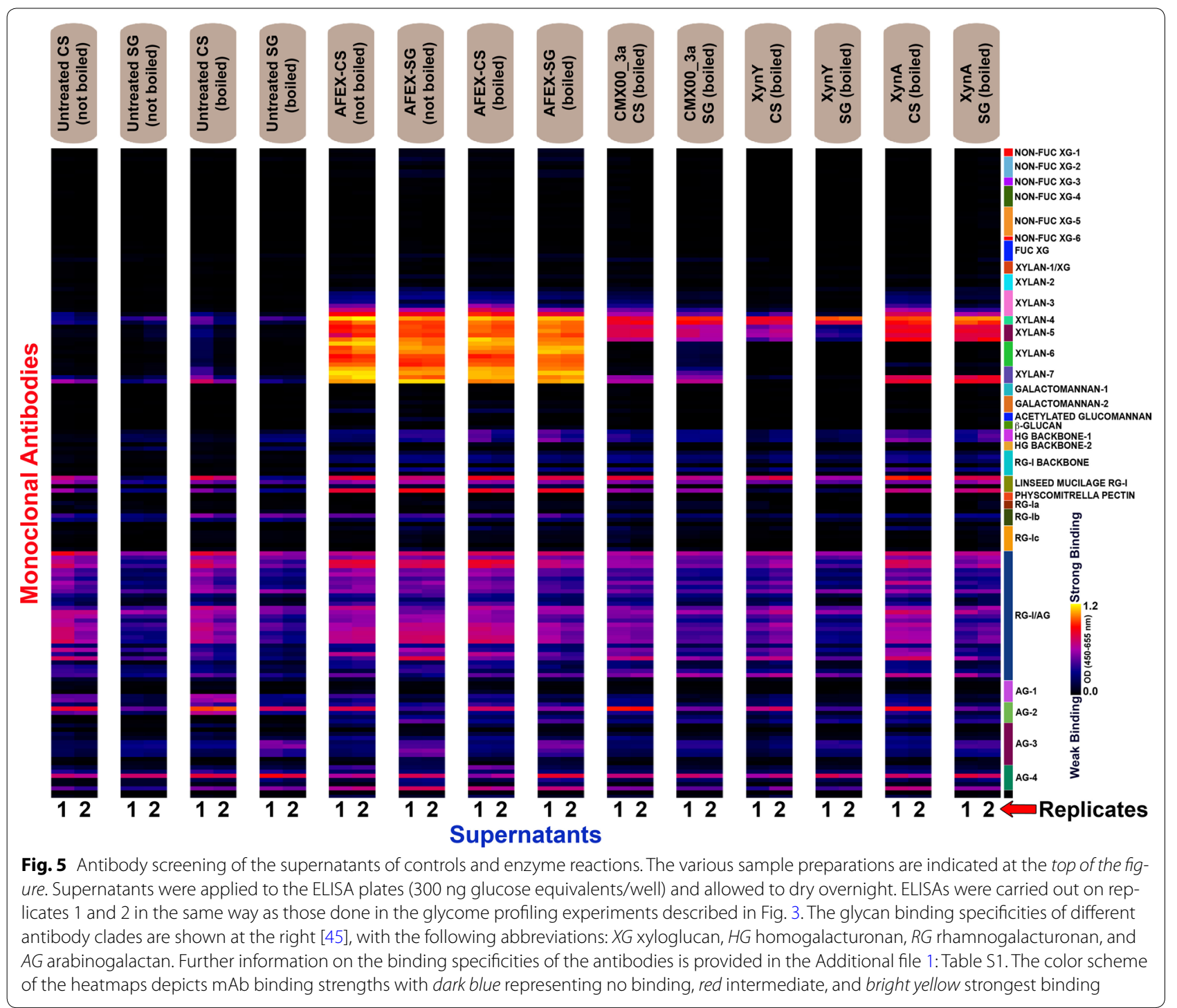

the IL-treated biomass than the AFEX-treated biomass [48]. XynY and XynA released pentose-containing oligosaccharides, consisting primarily of xylose and xylobiose (Tables 3,4), which is in accord with their activities on pure xylan (Table 2). CMX00_3a produced approximately half of the total pentose-derived products given by XynY and XynA (Tables 3, 4), but with a broader distribution of products and with xylotriose as the dominant product, as was observed previously with IL-treated SG [48].

Oxime-NIMS also revealed the formation of mixed pentose-hexose products, which are likely derived from substructures within xyloglucans or xylans (Fig. 6; Tables 3, 4). CMX00_3a yielded these as $\sim 8 \%$ of its total hydrolysis products from both corn stover and switchgrass, while reactions with XynA and XynY released 3\% or less of these mixed products. The masses of the mixed products are consistent with the following assignments, using the nomenclature for abbreviating xyloglucan substructures developed earlier [68]: xylose-1- $\alpha-6$-glucose (abbreviated $\mathrm{X}$, or less likely galactose-1- $\beta-2$-xylose); and (xylose-1- $\alpha-6$-glucose)-1- $\beta$-4-glucose (XG). XG was dominant product observed from all enzymes (Tables 3 , 4).

In addition, we observed mixed products with masses consistent with hexose-(pentose) ${ }_{2}$, and hexose(pentose) $)_{3}$, which are likely derived from substructures of xylan (Fig. 6; Tables 3, 4). CMX00_3a and XynY had similar activity for release of an oxime-NIMS product with $m / z=1379.56$ ( $4 \%$ total solubilized sugar), which is consistent with an assignment to Xyl-Rha-GalA-Xyl $(621.56 \mathrm{Da})$, a tetrasaccharide previously identified as being present at the reducing end of some xylans [69]. 
Table 3 Enzyme activities for AFEX-CS hydrolysis measured by oxime-NIMS

\begin{tabular}{|c|c|c|c|c|c|c|c|c|c|c|c|c|c|c|}
\hline \multirow{2}{*}{ No enzyme } & $\mathrm{G} 1(\mathrm{mM})$ & \multicolumn{2}{|c|}{ G2 (mM) } & \multicolumn{2}{|c|}{$\mathrm{G} 3(\mathrm{mM})$} & \multicolumn{2}{|c|}{$\mathrm{G} 4(\mathrm{mM})$} & \multicolumn{2}{|c|}{ Total (mM) } & \multicolumn{2}{|l|}{ Average (mM) } & \multicolumn{3}{|l|}{ Stdev } \\
\hline & 0.3 & 0.0 & & 0.0 & & 0.0 & & 0.3 & & - & & - & & \\
\hline \multirow[t]{2}{*}{ CMX00_3a } & 4.7 & 5.6 & & 0.1 & & 0.0 & & 10.4 & & & & & & \\
\hline & 4.9 & 8.2 & & 0.2 & & 0.1 & & 13.4 & & 11.9 & & 2.1 & & \\
\hline \multirow[t]{2}{*}{ XynY } & 0.0 & 0.0 & & 1.2 & & 0.2 & & 1.5 & & & & & & \\
\hline & 0.0 & 0.0 & & 1.4 & & 0.3 & & 1.7 & & 1.6 & & 0.2 & & \\
\hline \multirow[t]{3}{*}{ XynA } & 0.0 & 0.0 & & 0.1 & & 0.0 & & 0.1 & & & & & & \\
\hline & 0.0 & 0.0 & & 0.1 & & 0.0 & & 0.1 & & 0.1 & & 0.0 & & \\
\hline & P1 (mM) & P2 (mM) & & P3 (mM) & & P4 (mM) & & $\mathrm{mM})$ & P6 (mM) & Total (mN & & Average ( $r$ & M) & Stdev \\
\hline No enzyme & 0.0 & 0.0 & & 0.0 & & 0.0 & & & 0.0 & 0.0 & & - & & - \\
\hline \multirow[t]{2}{*}{ CMX00_3a } & 2.2 & 10.4 & & 13.1 & & 4.4 & & & 0.2 & 31.5 & & & & \\
\hline & 2.0 & 13.2 & & 19.2 & & 7.7 & & & 0.6 & 45.5 & & 38.5 & & 9.9 \\
\hline \multirow[t]{2}{*}{ XynY } & 95.2 & 129.1 & & 27.5 & & 9.5 & & & 0.1 & 262.4 & & & & \\
\hline & 84.7 & 138.3 & & 30.2 & & 13.8 & & & 0.1 & 268.8 & & 265.6 & & 4.5 \\
\hline \multirow[t]{3}{*}{ XynA } & 31.8 & 73.3 & & 0.2 & & 2.1 & & & 1.0 & 118.8 & & & & \\
\hline & 38.2 & 78.3 & & 0.2 & & 2.1 & & & 0.7 & 127.4 & & 123.1 & & 6.1 \\
\hline & $\mathrm{X}^{\mathrm{a}}(\mathrm{mM})$ & XG (mM) & $\mathrm{X} 2-$ & $\mathrm{G}(\mathrm{mM})$ & $\mathrm{X} 3-\mathrm{C}$ & $\mathrm{G}(\mathrm{mM})$ & Xyl- & -GalA & $y l(m M)$ & Total (mM) & Ave & age (mM) & Stdev & \\
\hline No enzyme & 0.0 & 0.0 & 0.0 & & 0.0 & & 0.0 & & & 0.0 & - & & - & \\
\hline \multirow[t]{2}{*}{ CMX00_3a } & 2.8 & 0.1 & 1.1 & & 0.2 & & 1.5 & & & 5.7 & & & & \\
\hline & 4.0 & 0.2 & 2.2 & & 0.4 & & 2.3 & & & 9.1 & 7.4 & & 2.4 & \\
\hline \multirow[t]{2}{*}{ XynY } & 0.7 & 0.0 & 0.1 & & 0.1 & & 7.7 & & & 8.6 & & & & \\
\hline & 0.6 & 0.0 & 0.2 & & 0.1 & & 10.1 & & & 11.0 & 9.8 & & 1.7 & \\
\hline \multirow[t]{2}{*}{ XynA } & 0.4 & 0.0 & 0.0 & & 0.0 & & 0.4 & & & 0.9 & & & & \\
\hline & 0.4 & 0.0 & 0.0 & & 0.0 & & 0.5 & & & 0.9 & 0.9 & & 0.0 & \\
\hline
\end{tabular}

Activity reported as $\mu \mathrm{mol}$ of reducing sugar released per hour per $\mu \mathrm{mol}$ of purified enzyme determined by oxime-NIMS as described in "Methods" section. Standard deviation indicated for the duplicate samples

AFEX-CS AFEX-treated corn stover, $G 1$ glucose, $G 2$ cellobiose, $G 3$ cellotriose, $G 4$ cellotetraose, $P 1$ pentose (i.e., likely xylose), $P 2$ pentobiose, $P 3$ pentotriose, $P 4$ pentotetraose, $P 5$ pentopentose, $P 6$ pentohexose

a Xyloglucan-derived oligosaccharides identified using abbreviations from [59]; X, Xyl-Glu; XG, Xyl-Glu-Glu; X2-G, Xyl-Xyl-Glc, X3-G, Xyl-Xyl-Xyl-Glc

This tetrasaccharide, which was detected in a larger amount in these samples of corn stover, has not been previously identified in grasses [70-72], but has been identified in dicots [73] and woody plants [74, 75].

\section{Discussion}

Individual enzymes from three different $\mathrm{GH}$ families known to hydrolyze hemicellulosic polysaccharides were studied for their activities on representative purified forms of hemicelluloses (e.g., oat spelt xylan, tamarind seed xyloglucan, wheat arabinoxylan) and also for their reactions with AFEX-treated corn stover and switchgrass using glycome profiling [45] and quantitative oximeNIMS [48]. The results presented here demonstrate that the combination of glycome profiling and oxime-NIMS allows one to clearly distinguish the three activities exhibited by these enzymes in reactions with plant biomass. Extension of this approach to other enzymes, different polysaccharides, and different plant biomasses has the potential to extend our specificity of understanding of enzyme specificity in a biofuel context. For example, pectic polysaccharides provide challenging, diverse structures that could be studied by the approach reported here. These studies would be enhanced by the use of additional techniques sensitive to stereochemical differences in sugars, such as high performance liquid or gas chromatography [76-79], which potentially allow further insight into the pentose product cascades identified by oxime-NIMS.

Table 5 provides a summary of the breadth of substrates hydrolyzed by each individual enzyme. The epitope recognized by XYLAN- 6 antibodies consists of at least four consecutive, unsubstituted $\beta-1,4$ linked xylose units [80] (also see Additional file 1: Table S1), and hydrolysis at any position within this epitope will lead to a loss of antibody binding. All four antibodies in the XYLAN-7 group bind to linear xylans of DP 4 or higher and can tolerate at least some level of arabinosyl substitution along the backbone [80]. XYLAN-7 antibodies recognize epitopes that consist of at least three $\beta-1,4$ linked xylose units; 
Table 4 Enzyme activities for AFEX-SG hydrolysis measured by oxime-NIMS

\begin{tabular}{|c|c|c|c|c|c|c|c|c|c|c|c|c|c|c|}
\hline \multirow{2}{*}{ No enzyme } & $\mathrm{G} 1(\mathrm{mM})$ & \multicolumn{2}{|c|}{ G2 (mM) } & \multicolumn{2}{|c|}{ G3 (mM) } & \multicolumn{2}{|c|}{$\mathrm{G} 4(\mathrm{mM})$} & \multicolumn{2}{|c|}{ Total (mM) } & \multicolumn{2}{|l|}{ Average (mM) } & \multicolumn{3}{|l|}{ Stdev } \\
\hline & 0.2 & 0.0 & & 0.0 & & 0.0 & & 0.58 & & - & & - & & \\
\hline \multirow[t]{2}{*}{ CMX00_3a } & 4.6 & 5.8 & & 0.2 & & 0.1 & & 8.54 & & & & & & \\
\hline & 4.5 & 5.0 & & 0.1 & & 0.0 & & 7.67 & & 10.2 & & 0.8 & & \\
\hline \multirow[t]{2}{*}{ XynY } & 0.0 & 1.3 & & 1.5 & & 0.2 & & 0.76 & & & & & & \\
\hline & 0.0 & 1.0 & & 1.0 & & 0.2 & & 0.54 & & 2.6 & & 0.6 & & \\
\hline \multirow[t]{3}{*}{ XynA } & 0.0 & 0.0 & & 0.0 & & 0.0 & & 0.02 & & & & & & \\
\hline & 0.0 & 0.0 & & 0.0 & & 0.0 & & 0.00 & & 0.0 & & 0.0 & & \\
\hline & P1 (mM) & P2 (mM) & & P3 (mM) & & P4 (mM) & & $n M)$ & P6 (mM) & Total (mM & & Average ( $r$ & M) & Stdev \\
\hline No enzyme & 0.0 & 0.0 & & 0.0 & & 0.0 & & & 0.0 & 0.0 & & - & & - \\
\hline \multirow[t]{2}{*}{ CMX00_3a } & 3.2 & 14.5 & & 17.3 & & 6.7 & & & 0.3 & 43.6 & & & & \\
\hline & 3.1 & 15.3 & & 17.0 & & 6.6 & & & 0.2 & 43.3 & & 43.4 & & 0.2 \\
\hline \multirow[t]{2}{*}{ XynY } & 94.5 & 127.9 & & 40.5 & & 10.5 & & & 0.1 & 274.6 & & & & \\
\hline & 93.1 & 143.3 & & 40.1 & & 12.0 & & & 0.0 & 289.5 & & 282.0 & & 10.5 \\
\hline \multirow[t]{3}{*}{ XynA } & 36.7 & 94.5 & & 0.3 & & 2.2 & & & 1.0 & 145.3 & & & & \\
\hline & 39.3 & 95.0 & & 0.1 & & 1.5 & & & 0.3 & 147.3 & & 146.3 & & 1.4 \\
\hline & $X^{a}(m M)$ & XG (mM) & $\mathrm{X} 2-$ & $\mathrm{G}(\mathrm{mM})$ & $\mathrm{X} 3-\mathrm{C}$ & (mM) & Xyl-1 & -GalA- & $y l(m M)$ & Total (mM) & Avera & age (mM) & Stdev & \\
\hline No enzyme & 0.0 & 0.0 & 0.0 & & 0.0 & & 0.0 & & & 0.0 & - & & - & \\
\hline \multirow[t]{2}{*}{ CMX00_3a } & 2.9 & 0.1 & 1.4 & & 0.2 & & 0.6 & & & 5.2 & & & & \\
\hline & 1.4 & 0.1 & 1.1 & & 0.2 & & 0.6 & & & 3.4 & 4.3 & & 1.3 & \\
\hline \multirow[t]{2}{*}{ XynY } & 0.4 & 0.0 & 0.2 & & 0.1 & & 2.6 & & & 3.3 & & & & \\
\hline & 0.4 & 0.0 & 0.2 & & 0.1 & & 2.5 & & & 3.1 & 3.2 & & 0.1 & \\
\hline \multirow[t]{2}{*}{ XynA } & 0.4 & 0.0 & 0.0 & & 0.0 & & 0.1 & & & 0.5 & & & & \\
\hline & 0.2 & 0.0 & 0.0 & & 0.0 & & 0.1 & & & 0.3 & 0.4 & & 0.1 & \\
\hline
\end{tabular}

Activity reported as $\mu \mathrm{mol}$ of reducing sugar released per hour per $\mu \mathrm{mol}$ of purified enzyme determined by oxime-NIMS as described in "Methods" section. Standard deviation indicated for the duplicate samples

AFEX-SG AFEX-treated switchgrass, $G 1$ glucose, $G 2$ cellobiose, $G 3$ cellotriose, $G 4$ cellotetraose, $P 1$ pentose (i.e., likely xylose), $P 2$ pentobiose, $P 3$ pentotriose, $P 4$ pentotetraose, $P 5$ pentopentose, $P 6$ pentohexose

a Xyloglucan-derived oligosaccharides identified using abbreviations from [59]; X, Xyl-Glu; XG, Xyl-Glu-Glu; X2-G, Xyl-Xyl-Glc, X3-G, Xyl-Xyl-Xyl-Glc

these antibodies can tolerate varying levels of arabinosyl substitution of the backbones [80]. CCRC-M154 binds to the arabinosyl side-chains of xylans; the antibody does not bind to the backbone xylosyl residues at all [80]. The XYLAN-5 antibodies bind to 4-O-methyl glucuronic acid substituted xylans that carry no acetyl substituents (unpublished results of the Hahn lab, in preparation).

XynY (GH10 xylanase) and XynA (GH11 xylanase) showed the highest specific activities with the oat spelt xylan polysaccharides and with the AFEX-treated biomass, consistent with their previously determined hydrolytic capabilities $[48,53,54]$. The presence of CBM6 in XynA and CBM22 in XynY, which both bind xylan, enhances their reactivity in ways that have been observed for other enzyme-CBM fusions [50, 81, 82]. In contrast, CBM3a present in CMX00_3a does not bind well to xylan $[59,60,63]$, which may have contributed to the lower specific activity for hydrolysis of xylan substrates. The ability of fusions of CBMs and catalytic domains to alter enzyme activity is widely known $[48,50,81$,
83-89]. Along this line, in our other work with CMX00, we showed that fusion to CBM44, which shows preferential binding to xylan relative to cellulose, yielded an enzyme that was more reactive with xylan and the hemicellulose fraction of IL-pretreated SG [50].

The activities of XynY and XynA could be clearly distinguished from one another, and from the activity of CMX00_3a. XynY appears to have the broadest activity against xylans in the plant cell wall, and completely or nearly completely degraded the epitopes recognized by the XYLAN-6 and XYLAN-7 antibodies, particularly in the oxalate, carbonate and chlorite extracts, and also cleaved essentially all epitopes bound by the XYLAN-3 antibodies in all wall extracts. XynY digestion of biomass also resulted in degradation of epitopes recognized by the XYLAN-4 and XYLAN-5 antibodies, again most prominently in the oxalate and carbonate extracts as well as in the supernatants from the enzyme reactions. XynY was also the most active enzyme on the glucuronoarabinoxylan epitopes, as judged by decrease in the intensity 

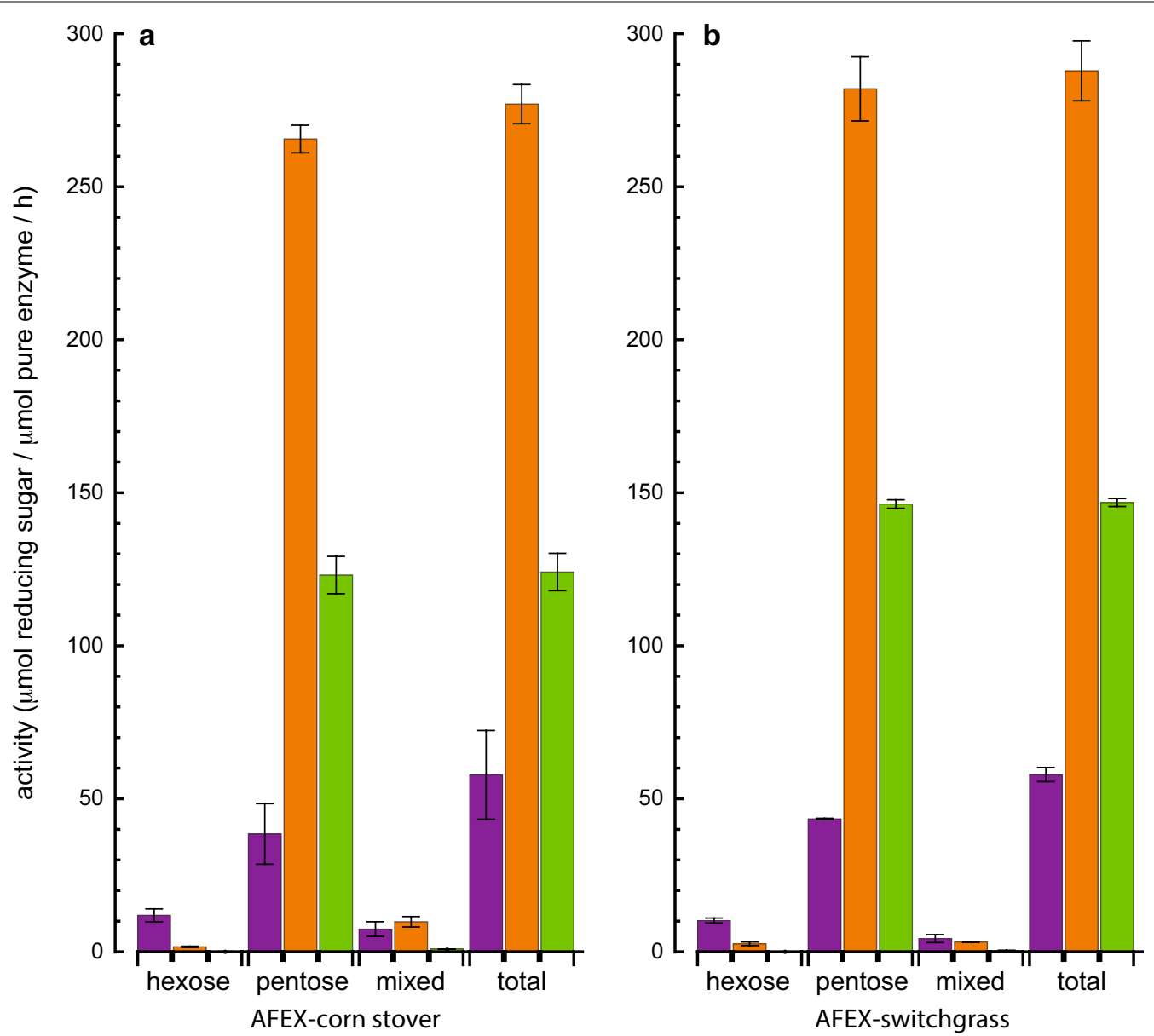

Fig. 6 Oxime-NIMS analysis of enzyme activity ( $\mu$ mol of reducing sugar released per $\mu$ mol of pure enzyme per hour at $55^{\circ} \mathrm{C}$ ) for different classes of reducing sugar products obtained from enzymatic hydrolysis of AFEX-corn stover or AFEX-switchgrass. Hexose products are derived from cellulose, while pentose and mixed pentose/hexose products (e.g., for mixed products, Xyl-Glc, Xyl-Xyl-Glc, Glc-Glc-Xyl, Xyl-Xyl-Xyl-Glc, Xyl-Rha-GalA-Xyl) are from various hemicellulose polysaccharides. Tables 3 and 4 list the concentrations of individual soluble oligosaccharides detected by NIMS in each of these categories. The color bars depict the different enzymes used: CMX00_3a (purple); XynY (orange); XynA (green)

of XYLAN-4 and XYLAN-5 in the glycome profiles and its reaction with arabinoxylan (Table 1; Fig. 2). This broad specificity is reasonable because many other members of GH10 are known to hydrolyze glycosidic bonds regardless of whether branched or unbranched xylose units are placed at the +1 and -1 positions of the catalytic site. In contrast, CMX00_3a (GH5) and XynA (GH11) are from $\mathrm{GH}$ families where the +1 and -1 sites of the catalytic sites are typically less accommodating of branching substitutions $[55,56]$. Tolerance of substitutions at the +1 and -1 positions would likely permit more options for reaction along a typical arabinoxylan chain, where up to $40 \%$ of the backbone molecules contain a branching substituent.

CMX00_3a was able to hydrolyze cellulose present in the pretreated biomass, which was not detected by glycome profiling, but was confirmed by oxime-NIMS (Tables 3, 4). The oxime-NIMS analysis also showed that neither XynY nor XynA hydrolyzed cellulose to any appreciable extent. CMX00_3a also reacted with xylan epitopes detected by the XYLAN-3, XYLAN-6, and XYLAN-7 antibodies, particularly in the oxalate and carbonate extracts, and also with epitopes recognized by antibodies for xyloglucan structures (Table 5).

XynA was the most selective of the three enzymes studies here. This enzyme was only effective in hydrolyzing epitopes recognized by the XYLAN- 6 antibodies in the oxalate and carbonate wall extracts and in the enzyme supernatants. XynA also hydrolyzed epitopes recognized by the XYLAN-7 antibodies, CCRC-M137 and CCRCM160, while apparently not hydrolyzing xylans recognized by the other two XYAN-7 antibodies, CCRC-M149 
Table 5 Summary of enzyme specificities detected by glycome profiling or oxime-NIMS

\begin{tabular}{|c|c|c|}
\hline Enzyme & GH family & Substrates identified ${ }^{a}$ \\
\hline \multirow[t]{10}{*}{ CMX00_3a } & \multirow[t]{10}{*}{ GH5 } & Oat spelt xylan $(\beta-1,4-x y l o s e)^{b}$ \\
\hline & & Tamarind seed xyloglucan ${ }^{c}$ \\
\hline & & Cellulose ( $\beta$-1,4-glucose) \\
\hline & & NON-FUC XG epitopes (structures not known) \\
\hline & & FUC-XG epitopes (structures not known) \\
\hline & & XYLAN-3 epitopes (structures not known) \\
\hline & & XYLAN-6 epitopes (unsubstituted xylan) ${ }^{d}$ \\
\hline & & XYLAN-7 epitopes (unsubstituted xylan) \\
\hline & & CCRC-M160 \\
\hline & & CCRC-M137 \\
\hline \multirow[t]{12}{*}{ XynY } & \multirow[t]{12}{*}{$\mathrm{GH} 10$} & Oat spelt xylan $(\beta-1,4-x y l o s e)^{b}$ \\
\hline & & Wheat arabinoxylan ${ }^{f}$ \\
\hline & & XYLAN-3 epitopes, structures not known \\
\hline & & XYLAN-4 epitopes \\
\hline & & CCRC-M154, arabinosylated-xylan \\
\hline & & $\begin{array}{l}\text { XYLAN-5 epitopes, methyl GlcA-substituted } \\
\text { xylan }\end{array}$ \\
\hline & & XYLAN-6 epitopes (unsubstituted xylan) ${ }^{4}$ \\
\hline & & XYLAN-7 epitopes (unsubstituted xylan) ${ }^{5}$ \\
\hline & & CCRC-M160 \\
\hline & & CCRC-M137 \\
\hline & & CCRC-M152 \\
\hline & & CCRC-M149 \\
\hline \multirow[t]{7}{*}{ XynA } & \multirow[t]{7}{*}{$\mathrm{GH} 11$} & Oat spelt xylan $(\beta-1,4-x y l o s e)^{b}$ \\
\hline & & Tamarind seed xyloglucanc \\
\hline & & Wheat arabinoxylan ${ }^{f}$ \\
\hline & & XYLAN-6 epitopes (unsubstituted xylan) ${ }^{d}$ \\
\hline & & XYLAN-7 epitopes (unsubstituted xylan) ${ }^{e}$ \\
\hline & & CCRC-M160 \\
\hline & & CCRC-M137 \\
\hline
\end{tabular}

\footnotetext{
a Reactions with purified hemicellulose polysaccharides detected by DNS; reaction with cellulose in AFEX-treated CS and SG detected by oxime-NIMS; reaction of hemicellulose fraction in CS and SG detected by glycome profiling and oxime-NIMS

${ }^{b} \beta-1,4-x y l o s e$ with $\sim 70: 15: 10$ composition of xylose:glucose:arabinose

c $\beta$-1,4-glucose with $\alpha-1,6$ xylose branching at on average, 3 out of 4 glucosyl backbone residues

d Stretches of unsubstituted $\beta-1,4-x y$ lan with at least four xylose units

e Stretches of unsubstituted $\beta-1,4-x y$ lan with at least three xylose units

${ }^{f} \beta-1,4$-xylose with $38: 62$ composition of arabinose and xylose, less than $1 \%$ of glucose, galactose, and mannose
}

and CCRC-M152. XynA was ineffective in degrading epitopes recognized by the XYLAN-3, -4 and -5 antibodies, nor was it able to effectively catalyze removal of xyloglucan epitopes.

The three enzymes had markedly different reactivities with isolated tamarind xyloglucan. As detected by DNS, CMX00_3a and XynA were able to degrade tamarind xyloglucan, while XynY showed only $\sim 1 / 1000$ of their activities (Fig. 2). Thus, it appears that XynY is not able to cleave the unbranched glucosyl residues in the xyloglucan backbone, while CMX00_3a and XynA are able to cleave these residues to a certain extent, at least in isolated tamarind xyloglucan. Interestingly, XynA appeared to have no effect on xyloglucans in AFEX pre-treated biomass samples. The reactivity of CMX00_3a (GH5_4) with tamarind seed xyloglucan as detected by DNS and MALDI-MS was consistent with its ability to degrade xyloglucan epitopes in the $1 \mathrm{M} \mathrm{KOH}$ extracts of pretreated grasses as judged by glycome profiling (Figs. 4, 5) and by the appearance of mixed pentose-hexose products detected by oxime-NIMS. While oxime-NIMS did not detect small soluble products of tamarind seed xyloglucan hydrolysis (e.g., glucose, xylose), MALDI showed accumulation of longer insoluble xyloglucan oligosaccharides such as $\mathrm{Glc}_{4}-\mathrm{Xyl}_{3}, \mathrm{Glc}_{5}-\mathrm{Xyl}_{4}$, and $\mathrm{Glc}_{6}-\mathrm{Xyl}_{5}$, representing highly branched portions of the polysaccharide that could not be hydrolyzed.

Xylanases from GH11 have not been previously reported to hydrolyze $\beta-1,4$ linked glucose $[57,58,90]$, which forms the backbone of xyloglucan. However, xylanases from GH11 and cellulases from GH12 share the same $\beta$-jelly roll protein fold and have spatially comparable active site residues. Thus, XynA may have other active site feature(s) of GH12 needed for reaction with substituted $\beta-1,4$ linked glucose backbones [58, 91, 92]. This potential broadening of specificity in the $\beta$-jelly roll fold of GH11 and GH12 can be contrasted with the specificities of the $(\alpha \beta)_{8}$ barrel folds of CMX00 (GH5_4) and (XynY) GH10, where CMX00 reacts with cellulose ( $\beta-1,4$ linked glucose), xylan ( $\beta-1,4$ linked xylose), and xyloglucan ( $\beta-1,4$ linked glucose with $\alpha-1,6$ linked branching), while XynY only reacted with xylan ( $\beta-1,4$ linked xylose) and arabinoxylan and did not react with either xyloglucan or cellulose [54, 58, 90, 93]. Identification of the features that control divergent specificity for polysaccharide backbones and tolerance to branching in closely related protein folds is a matter of ongoing investigation in many laboratories.

\section{Conclusions}

Glycome profiling was used to observe the consequences of enzyme hydrolysis on AFEX-treated plant cell walls and proved capable of distinguishing the activities of related enzymes. Enzymes from GH5, GH10, and GH11 were demonstrated to hydrolyze at least some xyloglucan and/or xylans both in vitro and in AFEX-pretreated biomass. The GH10 enzyme, XynY, proved to be reactive with the broadest diversity of xylose-backbone polysaccharide epitopes, but was incapable of reacting with glucose-backbone polysaccharides. In contrast, the GH5 and GH11 enzymes studied here showed the ability to react 
with both glucose- and xylose-backbone polysaccharides (at least in vitro), a potentially useful breadth of specificity given the complexity of plant biomass. The methods used in this work provide a complementary view of GH function with relatively intact plant cell walls, and offer new insights into how additional specific hemicellulose substructures could be targeted for more efficient hydrolysis by simple combinations of pretreatment, enzymes, and CBMs.

\section{Methods}

\section{Cloning, expression, and purification of enzymes}

The cloning of CMX00_3a and XynY into the wheat germ cell-free translation plasmid pEU was described previously $[48,52]$. The cloned gene sequences were transferred from the cell-free expression plasmid by digestion with $S g f \mathrm{I}$ and $B a m \mathrm{HI}$, and ligation into similarly digested pVP67K, a lactose inducible expression vector for use in Escherichia coli [94].

For protein expression, pVP67K plasmids were transformed into competent Escherichia coli BL21-CodonPlus (DE3)-RILP cells (Agilent Technologies, Santa Clara, CA, USA). CMX00_3a and XynY used in this work were produced using auto-induction expression [95] at the DOE Advanced Bioprocessing Demonstration Unit (Lawrence Berkeley National Laboratory, Emeryville, CA, USA) and purified using HisTrap column chromatography at KanPro Research, Inc. (Lawrence, KS, USA). The yield of purified CMX00_3a after expression in E. coli and purification using metal affinity chromatography was $\sim 0.45 \mathrm{~g} / \mathrm{L}$ of culture medium. The yield of purified XynY after expression in E. coli and $\mathrm{Ni}^{2+}$-immobilized metal affinity chromatography was $\sim 0.6 \mathrm{~g} / \mathrm{L}$ of culture medium.

XynA was cloned from $R$. thermocellum genomic DNA using forward primer $5^{\prime}$-CTGTACTTCCAGGCGATCG CCgatgtagtaattacgtcaaaccagacg- $3^{\prime}$ and reverse primer $5^{\prime}$-TCGAATTCGTTTAAACTACTAcgagtcgaatatgaagtagtcaatgtt- $3^{\prime}$, and polymerase incomplete primer extension [96]. The plasmid pVP67K was amplified with forward primer 5'-GGCGATCGCCTGGAAGTAC

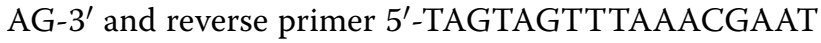
TCGA- $3^{\prime}$. Uppercase letters represent the overlapping nucleotides of the amplified XynA gene and pVP67K that are annealed during transformation, and the lowercase letters are the nucleotides of the XynA gene. The cloned XynA consisted of the GH11 catalytic domain and a C-terminal CBM6 domain. pVP67K and XynA were amplified in separate PCR reactions, then $2 \mu \mathrm{L}$ of each were mixed together and transformed into competent E. cloni 10G cells (Lucigen Corporation, Middleton, WI, USA). Kanamycin-resistant transformants were sequenced to identify inserts with the correct gene sequence using forward primer $5^{\prime}$-TTGCTTTGTGAGCGGATAAC-3' and reverse primer 5'-GCTAGTTATTGCTCAGCGG-3'.

XynA was expressed using auto-induction and purified as follows: Cells containing the XynA plasmid were grown for $12 \mathrm{~h}$ at room temperature in 500-mL Erlenmeyer flasks containing $50 \mathrm{~mL}$ of non-inducing medium and subsequently split and transferred into two 2-L plastic baffled bottles containing $0.5 \mathrm{~L}$ of auto-induction medium for $25 \mathrm{~h}$ with shaking at room temperature [95]. The cells were harvested by centrifugation; the cell pellet was re-suspended in $100 \mathrm{mM}$ MOPS, $\mathrm{pH}$ 7.4, containing $0.5 \mathrm{M} \mathrm{NaCl}, 20 \mathrm{mM}$ imidazole, $1 \mathrm{mM}$ EDTA, $1.0 \mu \mathrm{M}$ E-64 (Sigma-Aldrich, St. Louis, MO, USA), and $0.5 \mathrm{mM}$ benzamidine (EMD Millipore, Darmstadt, Germany). The suspended cells were sonicated with a 15-s on/off cycle on wet ice for a total of 10-min sonication time. The sonicated lysate was centrifuged and the supernatant was loaded onto a HisTrap column (GE Healthcare, Piscataway, NJ, USA) equilibrated with $100 \mathrm{mM}$ MOPS, $\mathrm{pH}$ 7.4, containing $0.5 \mathrm{M} \mathrm{NaCl}$ and $20 \mathrm{mM}$ imidazole. After lysate loading, the column was washed with $\sim 3$ column volumes of the equilibration buffer and then a linear gradient with $100 \mathrm{mM}$ MOPS, $\mathrm{pH} 7.4$, containing $0.5 \mathrm{M} \mathrm{NaCl}$, and $0.5 \mathrm{M}$ imidazole was used to elute the protein. Fractions containing pure protein were identified by denaturing gel electrophoresis, pooled, concentrated, and buffer exchanged into $10 \mathrm{mM}$ MOPS, $\mathrm{pH} 7$ containing $50 \mathrm{mM} \mathrm{NaCl}$ using Vivaspin 20 centrifugal concentrators (Sartorius Stedim, Bohemia, NY, USA). The yield of purified XynA after expression in E. coli and $\mathrm{Ni}^{2+}$ immobilized metal affinity chromatography was $\sim 0.3 \mathrm{~g} / \mathrm{L}$ of culture medium.

\section{Enzyme reactions}

Untreated and ammonia fiber expansion (AFEX) pretreated corn stover and switchgrass [33] grown during 2010 were provided by Dr. Bruce E. Dale (Great Lakes Bioenergy Research Center). Compositional analyses of the corn stover and switchgrass were performed using NREL procedures LAP-002 and LAP-005 [97-99]. For corn stover, the percentage compositions of the untreated, dry biomass $(\mathrm{w} / \mathrm{w})$ were $30.7 \%$ glucan, $18.5 \%$ xylan, $1.2 \%$ galactan, $3.1 \%$ arabinan, $14.3 \%$ lignin, $3.2 \%$ protein, and $13.4 \%$ ash. For switchgrass, the percentage compositions of the untreated, dry biomass was $34.2 \%(\mathrm{w} / \mathrm{w})$ glucan, $21.5 \%$ xylan, $1.4 \%$ galactan, $2.3 \%$ arabinan, $18.6 \%$ lignin, $3.2 \%$ protein, and $5.6 \%$ ash. Oat spelt xylan ( $>70 \%$ purity with $\sim 70: 15: 10$ composition of xylose:glucose:arabinose) was from Sigma-Aldrich (St. Louis, MO, USA), and tamarind xyloglucan ( 95\% purity with 3:18:34:45 composition of arabinose:galactose:xylo se:glucose) and low viscosity wheat arabinoxylan ( $95 \%$ 
purity with 38:62 composition of arabinose and xylose, less than $1 \%$ of glucose, galactose, and mannose) were from Megazyme (Wicklow, Ireland).

Oat spelt xylan was prepared $[100,101]$ by boiling two grams of the polysaccharide in $100 \mathrm{~mL}$ of distilled water for $30 \mathrm{~min}$ and subsequently pelleting the insoluble fraction by centrifugation for $20 \mathrm{~min}$ at $4300 \times g$ at $4{ }^{\circ} \mathrm{C}$. The insoluble xylan pellet was washed three times by centrifugation for $20 \mathrm{~min}$ at $4300 \times g$ at $4{ }^{\circ} \mathrm{C}$ and placed at $-80{ }^{\circ} \mathrm{C}$ overnight. The sample was lyophilized to obtain $\sim 1 \mathrm{~g}$ of the final insoluble substrate.

Enzyme assays with pure substrates contained $1 \mathrm{mg}$ of either xylan, xyloglucan, or arabinoxylan mixed with $20 \mu \mathrm{g}$ of CMX00_3a $(60,118 \mathrm{Da}, 0.33 \mathrm{nmol}$ of active sites), $8 \mu \mathrm{g}$ of XynY (78,573 Da, $0.10 \mathrm{nmol}$ of active sites), or $8 \mu \mathrm{g}$ of XynA $(40,317 \mathrm{Da}, 0.20 \mathrm{nmol}$ of active sites) in $100 \mu \mathrm{L}$ of $50 \mathrm{mM}$ sodium phosphate, $\mathrm{pH}$, containing $1 \mathrm{mg} / \mathrm{mL}$ bovine serum albumin to mitigate nonspecific binding of enzyme. Control reactions with no enzyme substituted buffer for the volume of added enzyme. Reactions were shaken at $1200 \mathrm{rpm}$ and $55{ }^{\circ} \mathrm{C}$ within a Heidolph Titramax 1000/Incubator 1000 combination (Heidolph North American, Elk Grove Village, IL, USA). After $24 \mathrm{~h}$, the reactions were cooled on ice for $5 \mathrm{~min}$ to stop the reactions and centrifuged at $4000 \times g$ for $10 \mathrm{~min}$ at $4{ }^{\circ} \mathrm{C}$, and the supernatant fractions were collected for the determination of reducing sugar amounts using the dinitrosalicylic acid (DNS) assay [50, 52, 102]. For the DNS reaction, the appropriately diluted supernatant $(30 \mu \mathrm{L})$ was added to $60 \mu \mathrm{L}$ of DNS reagent [1\% $(\mathrm{w} / \mathrm{v})$ 3,5-dinitrosalicylic acid, Sigma-Aldrich, $0.2 \%(\mathrm{v} / \mathrm{v})$ phenol, $0.05 \%(\mathrm{w} / \mathrm{v})$ sodium sulfite, and $1 \%(\mathrm{w} / \mathrm{v})$ sodium hydroxide] and boiled at $95{ }^{\circ} \mathrm{C}$ for $5 \mathrm{~min}$. After boiling, the absorbance of the samples was measured at $540 \mathrm{~nm}$, and D-glucose standards were used to calculate reducing sugar concentrations. All reactions were performed in triplicate.

For enzyme reactions to prepare solid samples for glycome profiling and supernatant samples for antibody screening and for oxime-NIMS, $1 \mathrm{~g}$ of substrate (i.e., untreated or AFEX-treated corn stover or switchgrass) was mixed with $20 \mathrm{mg}$ of CMX00_3a $(0.3 \mu \mathrm{mol}$ of active sites), $8 \mathrm{mg}$ of XynY (0.1 $\mu \mathrm{mol}$ of active sites), or $8 \mathrm{mg}$ of XynA $(0.2 \mu \mathrm{mol}$ of active sites) in $10 \mathrm{~mL}$ of $50 \mathrm{mM}$ sodium phosphate, $\mathrm{pH} 6$, containing $1 \mathrm{mg} / \mathrm{mL}$ bovine serum albumin. All reactions were performed in duplicate. In control samples lacking enzyme, $10 \mathrm{mM}$ MOPS, $\mathrm{pH} 7$, containing $50 \mathrm{mM} \mathrm{NaCl}$ was used to replace the volume of enzyme added. Reactions were incubated at $55{ }^{\circ} \mathrm{C}$ while shaking on a Thermo Scientific Titer Plate Shaker (Model No. 4625) (Thermo Fisher Scientific, Waltham, MA, USA) for $24 \mathrm{~h}$. Indicated control reactions and all enzyme reactions were stopped by placing the reaction vessel in a $95{ }^{\circ} \mathrm{C}$ water bath for 5 min ('boiled' samples). The samples were centrifuged at $4000 \times g$ for 15 min at $4{ }^{\circ} \mathrm{C}$, and the supernatant and solid fractions were separated. The supernatant fractions were filtered using a $0.2 \mu \mathrm{m}$ filter and frozen with liquid $\mathrm{N}_{2}$. Both supernatant and solid fractions were stored at $-80{ }^{\circ} \mathrm{C}$ until needed. All supernatants and cell wall extracts were lyophilized before glycome profiling processing. Aliquots $(100 \mu \mathrm{L})$ of the filtered supernatants were taken to measure reducing sugar concentrations using the DNS assay and to perform oxime-NIMS analyses [48, 49]. The DNS assay was carried out as mentioned above. Oxime-NIMS methods are described below.

\section{Glycome profiling}

Glycome profiling involves using an increasingly harsh series of extractions of plant cell wall material to yield wall extracts that contain mixtures of most major noncellulosic cell wall glycans including hemicelluloses and pectic polysaccharides $[45,47]$. These extracts are then screened by ELISA [45] using a comprehensive suite of cell wall glycan-directed mAbs [44, 45, 103, 104] for detecting diverse glycan epitopes present in the noncellulosic glycans (Additional file 1: Table S1). Loosely attached polysaccharides are removed during the early extractions (oxalate and carbonate) while more tightly bound polysaccharides are freed by the harshest extractions ( $1 \mathrm{M} \mathrm{KOH}, 4 \mathrm{M} \mathrm{KOH}$, chlorite, and $4 \mathrm{M} \mathrm{KOHPC}$ ).

Glycome profiling of various biomass samples (including untreated, pretreated and enzyme hydrolyzed samples) was done as described earlier [37, 45, 46, 71]. Supernatants were also subjected to screening with the entire collection of cell wall glycan-directed monoclonal antibodies used for glycome profiling. The cell wall glycan-directed antibodies used in glycome profiling analyses and screening of supernatants [44] were procured from laboratory stocks (CCRC, JIM, and MAC series) at the Complex Carbohydrate Research Center (available through CarboSource Services; http://www.carbosource. net) and also from BioSupplies (Australia) (BG1, LAMP).

\section{Oxime-NIMS methods}

Soluble products in the supernatants of the hydrolysis reactions of various biomass samples (including untreated, pretreated and enzyme hydrolyzed samples) were detected using oxime-NIMS. Synthesis of the $O$-alkyloxyamine fluorous tagged NIMS reagent has been published [48]. Supernatant samples for oximeNIMS analysis were prepared as described above. A $2 \mu \mathrm{L}$ aliquot of the supernatant was transferred into a vial containing $6 \mu \mathrm{L}$ of $100 \mathrm{mM}$ glycine acetate, $\mathrm{pH} 1.2,1.0$ $\mu \mathrm{L}$ of a mixture of $2.5 \mathrm{mM}$ aqueous solution of $[U]-{ }^{13} \mathrm{C}$ glucose and $2.5 \mathrm{mM}$ aqueous solution of $[U]-{ }^{13} \mathrm{C}$ xylose, 
$2 \mu \mathrm{L}$ of $\mathrm{CH}_{3} \mathrm{CN}, 1 \mu \mathrm{L}$ of $\mathrm{MeOH}, 1 \mu \mathrm{L}$ of the NIMS probe (100 mM in $\left.1: 1(\mathrm{v} / \mathrm{v}) \mathrm{H}_{2} \mathrm{O}: \mathrm{MeOH}\right)$, and $0.1 \mu \mathrm{L}$ of aniline. The sample was incubated at room temperature for $16 \mathrm{~h}$, and then a $0.12 \mu \mathrm{L}$ aliquot was spotted onto the surface of the NIMS chip and removed after $30 \mathrm{~s}$. A grid drawn manually on the NIMS chip using a diamond-tip scribe helped with spotting and identification of sample spots in the spectrometer. NIMS chips were loaded using a modified standard MALDI plate and analyzed using a 5800 MALDI TOF/TOF mass spectrometer (Applied Biosystems, Foster City, CA, USA). Signal intensities were identified for product ions and 1000 laser shots were collected for each sample spot. Product quantitation was achieved by using either $[U]-{ }^{13} \mathrm{C}$ glucose or $[U]-{ }^{13} \mathrm{C}$ xylose as an internal standard.

\section{MALDI-MS methods}

High molecular weight insoluble products in the supernatants of the hydrolysis reactions of tamarind seed xyloglucan hydrolysis were detected using MALDI-MS. The matrix used was either Universal MALDI Matrix (Aldrich, St. Louis, MO, USA) or $\alpha$-cyano-4-hydroxycinnamic acid (Aldrich, St. Louis, MO, USA) dissolved in methanol with $0.1 \%$ trifluoroacetic acid with concentration of $30 \mathrm{mg} / \mathrm{mL}$. The samples and the matrices were mixed in a 1:1 ratio and $0.5 \mu \mathrm{L}$ of the resulting mixture were deposited onto an Opti-TOF 384 well MALDI plate. The air-dried samples were analyzed using a 5800 MALDI TOF/TOF mass spectrometer (Applied Biosystems, Foster City, CA, USA). The operating mode was either MS Reflector Positive or Linear Mid Mass Range.

\section{Additional file}

Additional file 1: Table S1. Detailed list of cell wall glycan-directed monoclonal antibodies (mAbs) used for glycome profiling analyses.

\section{Abbreviations \\ GH: glycoside hydrolase; CBM: carbohydrate binding module; CMX00: broad specificity GH family 5 (GH5) domain from $R$. thermocellum Cthe_0797; AFEX- CS: ammonia fiber expansion-pretreated corn stover; AFEX-SG: ammonia fiber expansion-pretreated switchgrass; NIMS: nanostructure-initiator mass spectrometry.}

\section{Authors' contributions}

JAW, SP, LFB, ETB, MGH, and BGF designed the enzyme digestion and glycome profile experiments. JAW, LFB, and ETB carried out cloning, expression, purification and assays, analyzed results, and prepared the manuscript. SP, MM, and MGH carried out glycome profiling experiments, analyzed results, and prepared the manuscript. KD, TRN, and BGF designed and carried out mass spectrometry experiments, analyzed results, and prepared the manuscript. All authors read and approved the final manuscript.

\section{Author details}

${ }^{1}$ US Department of Energy Great Lakes Bioenergy Research Center, University of Wisconsin-Madison, Madison, WI 53706, USA. ${ }^{2}$ Department of Biochemistry, University of Wisconsin-Madison, Madison, WI 53706, USA. ${ }^{3}$ US Department of Energy Bioenergy Science Center, Oak Ridge National Laboratory, Oak
Ridge, TN 37831, USA. ${ }^{4}$ Complex Carbohydrate Research Center, University of Georgia, Athens, GA 30602, USA. ${ }^{5}$ US Department of Energy Joint Bioenergy Institute, Emeryville, CA 94608, USA. ${ }^{6}$ Sandia National Laboratories, Livermore, CA 94551, USA. ${ }^{7}$ Lawrence Berkeley National Laboratory, Berkeley, CA 94720, USA.

\section{Acknowledgements}

Not applicable.

\section{Competing interests}

$\mathrm{KD}$ and TRN are co-inventors on a patent application that covers the oximeNIMS assay. BGF is an inventor on a patent that covers use of multifunctional enzymes. The authors have no non-financial competing interests.

\section{Availability of data and materials}

The datasets used and/or analyzed during the current study are available from the corresponding author on reasonable request.

\section{Funding}

The DOE Great Lakes Bioenergy Research Center, DOE Joint BioEnergy Institute, and DOE Bioenergy Sciences Center are supported by the US Department of Energy, Office of Science, Office of Biological and Environmental Research, through contracts DE-FC02-07ER64494, DE-AC02-05CH11231, and DE-PS02-717 06ER64304, respectively. The generation of the plant glycandirected monoclonal antibodies used in this study was funded by grants from the US National Science Foundation Plant Genome Program to M.G.H. (DBI-0421683 and IOS-0923992). J.A.W. was supported by the UW-Madison Science and Medicine Graduate Research Scholars Advanced Opportunity Fellowship Program, the National Institute of General Medical Sciences Molecular Biophysics Training Program (NIHT32 GM08293), and a National Science Foundation Graduate Research Fellowship (DGE-1256259). The funding bodies have no role in the design of the study and collection, analysis, and interpretation of data and in writing the manuscript.

Received: 28 September 2016 Accepted: 6 January 2017

Published online: 02 February 2017

\section{References}

1. Soratana K, Harden CL, Zaimes GG, Rasutis D, Antaya CL, Khanna V, Landis AE. The role of sustainability and life cycle thinking in U.S. biofuels policies. Energy Policy. 2014;75:316-26.

2. Zhang $\mathrm{YH}$. Reviving the carbohydrate economy via multi-product lignocellulose biorefineries. J Ind Microbiol Biotechnol. 2008;35(5):367-75.

3. Salunkhe DK. World oilseeds: chemistry, technology, and utilization. New York: Van Nostrand Reinhold; 1992.

4. Dale BE, Leong CK, Pham TK, Esquivel VM, Rios I, Latimer VM. Hydrolysis of lignocellulosics at low enzyme levels: application of the AFEX process. Bioresour Technol. 1996;56(1):111-6.

5. Lynd LR, Wyman CE, Gerngross TU. Biocommodity engineering. Biotechnol Prog. 1999;15(5):777-93.

6. Jordan DB, Bowman MJ, Braker JD, Dien BS, Hector RE, Lee CC, Mertens JA, Wagschal K. Plant cell walls to ethanol. Biochem J. 2012:442(2):241-52.

7. Jarvis MC, Forsyth W, Duncan HJ. A survey of the pectic content of nonlignified monocot cell walls. Plant Physiol. 1988:88(2):309-14.

8. Carpita NC, Gibeaut DM. Structural models of primary cell walls in flowering plants: consistency of molecular structure with the physical properties of the walls during growth. Plant J. 1993;3(1):1-30.

9. Carpita NC. Structure and biogenesis of the cell walls of grasses. Annu Rev Plant Physiol Plant Mol Biol. 1996;47:445-76.

10. Cosgrove DJ. Wall structure and wall loosening. A look backwards and forwards. Plant Physiol. 2001;125(1):131-4.

11. Somerville C, Bauer S, Brininstool G, Facette M, Hamann T, Milne J, Osborne E, Paredez A, Persson S, Raab T, et al. Toward a systems approach to understanding plant cell walls. Science. 2004:306(5705):2206-11.

12. Harris D, DeBolt S. Synthesis, regulation and utilization of lignocellulosic biomass. Plant Biotechnol J. 2010;8(3):244-62. 
13. Gibson $\amalg$. The hierarchical structure and mechanics of plant materials. J Royal Soc Interface. 2012;9(76):2749-66.

14. Atmodjo MA, Hao Z, Mohnen D. Evolving views of pectin biosynthesis. Annu Rev Plant Biol. 2013;64:747-79.

15. Hao Z, Mohnen D. A review of xylan and lignin biosynthesis: foundation for studying Arabidopsis irregular xylem mutants with pleiotropic phenotypes. Crit Rev Biochem Mol Biol. 2014;49(3):212-41.

16. Tan L, Eberhard S, Pattathil S, Warder C, Glushka J, Yuan C, Hao Z, Zhu $X$, Avci U, Miller JS, et al. An Arabidopsis cell wall proteoglycan consists of pectin and arabinoxylan covalently linked to an arabinogalactan protein. Plant Cell. 2013;25(1):270-87.

17. Cornuault V, Buffetto F, Rydahl MG, Marcus SE, Torode TA, Xue J, Crepeau MJ, Faria-Blanc N, Willats WG, Dupree P, et al. Monoclonal antibodies indicate low-abundance links between heteroxylan and other glycans of plant cell walls. Planta. 2015;242:1321.

18. Scheller HV, Ulvskov P. Hemicelluloses. Annu Rev Plant Biol. 2010;61:263-89.

19. Pauly M, Gille S, Liu L, Mansoori N, de Souza A, Schultink A, Xiong G. Hemicellulose biosynthesis. Planta. 2013;238(4):627-42.

20. Girio FM, Fonseca C, Carvalheiro F, Duarte LC, Marques S, BogelLukasik R. Hemicelluloses for fuel ethanol: a review. Bioresour Technol. 2010:101(13):4775-800.

21. Ebringerová A, Hromádková Z, Heinze T. Hemicellulose. In: Heinze T, editor. Polysaccharides I, vol 186. Berlin: Springer; 2005. p. 1-67.

22. Grabber JH. How do lignin composition, structure, and cross-linking affect degradability? A review of cell wall model studies. Crop Sci. 2005;45(3):820-31.

23. Buanafina MM, Langdon T, Hauck B, Dalton SJ, Morris P. Manipulating the phenolic acid content and digestibility of italian ryegrass (Lolium multiflorum) by vacuolar-targeted expression of a fungal ferulic acid esterase. Appl Biochem Biotechnol. 2006;129-132:416-26.

24. Buanafina MM, Langdon T, Hauck B, Dalton S, Morris P. Expression of a fungal ferulic acid esterase increases cell wall digestibility of tall fescue (Festuca arundinacea). Plant Biotechnol J. 2008;6(3):264-80.

25. Pauly M, Keegstra K. Biosynthesis of the plant cell wall matrix polysaccharide xyloglucan. Annu Rev Plant Biol. 2016;67:235.

26. Brennan M, Harris PJ. Distribution of fucosylated xyloglucans among the walls of different cell types in monocotyledons determined by immunofluorescence microscopy. Mol Plant. 2011;4(1):144-56.

27. Moreira LRS, Filho EXF. An overview of mannan structure and mannandegrading enzyme systems. Appl Microbiol Biotechnol. 2008;79(2):165-78.

28. Yamabhai M, Sak-Ubol S, Srila W, Haltrich D. Mannan biotechnology: from biofuels to health. Crit Rev Biotechnol. 2016;36(1):32-42.

29. Harholt J, Suttangkakul A, Vibe Scheller H. Biosynthesis of pectin. Plant Physiol. 2010;153(2):384-95.

30. Xu Z, Huang F. Pretreatment methods for bioethanol production. Appl Biochem Biotechnol. 2014;174(1):43-62.

31. Mosier N, Wyman C, Dale B, Elander R, Lee YY, Holtzapple M, Ladisch M. Features of promising technologies for pretreatment of lignocellulosic biomass. Bioresour Technol. 2005;96(6):673-86.

32. Chundawat SP, Beckham GT, Himmel ME, Dale BE. Deconstruction of lignocellulosic biomass to fuels and chemicals. Annu Rev Chem Biomol Eng. 2011;2:121-45.

33. Balan V, Bals B, Chundawat SP, Marshall D, Dale BE. Lignocellulosic biomass pretreatment using AFEX. Methods Mol Biol. 2009;581:61-77.

34. Holtzapple M, Jun J-H, Ashok G, Patibandla S, Dale B. The ammonia freeze explosion (AFEX) process. Appl Biochem Biotechnol. 1991;28-29(1):59-74.

35. Lau MW, Gunawan C, Dale BE. The impacts of pretreatment on the fermentability of pretreated lignocellulosic biomass: a comparative evaluation between ammonia fiber expansion and dilute acid pretreatment. Biotechnol Biofuels. 2009;2:30-30.

36. Chundawat SP, Vismeh R, Sharma LN, Humpula JF, da Costa Sousa L, Chambliss CK, Jones AD, Balan V, Dale BE. Multifaceted characterization of cell wall decomposition products formed during ammonia fiber expansion (AFEX) and dilute acid based pretreatments. Bioresour Technol. 2010;101(21):8429-38.

37. Pattathil S, Hahn MG, Dale BE, Chundawat SP. Insights into plant cell wall structure, architecture, and integrity using glycome profiling of native and AFEX ${ }^{\mathrm{TM}}$-pre-treated biomass. J Exp Bot. 2015;66(14):4279-94.
38. da Costa Sousa L, Jin M, Chundawat S, Bokade V, Tang X, Azarpira A, Lu F, Avci U, Humpula J, Uppugundlam N, et al. Next-generation ammonia pretreatment enhances biofuel production from biomass via simultaneous cellulose decrystallization and lignin extraction. Energy Environ Sci. 2016:9:1215-23.

39. Lombard V, Golaconda Ramulu H, Drula E, Coutinho PM, Henrissat B. The carbohydrate-active enzymes database (CAZy) in 2013. Nucleic Acids Res. 2014;42(Database issue):D490-5.

40. Gilbert HJ, Stalbrand H, Brumer H. How the walls come crumbling down: recent structural biochemistry of plant polysaccharide degradation. Curr Opin Plant Biol. 2008;11(3):338-48.

41. Kumar R, Singh S, Singh OV. Bioconversion of lignocellulosic biomass: biochemical and molecular perspectives. J Ind Microbiol Biotechnol. 2008;35(5):377-91.

42. Dodd D, Cann IK. Enzymatic deconstruction of xylan for biofuel production. Glob Change Biol Bioenergy. 2009;1 (1):2-17.

43. Mohanram S, Amat D, Choudhary J, Arora A, Nain L. Novel perspectives for evolving enzyme cocktails for lignocellulose hydrolysis in biorefineries. Sus Chem Processes. 2013;1 (1):1-12.

44. Pattathil S, Avci U, Baldwin D, Swennes AG, McGill JA, Popper Z, Bootten T, Albert A, Davis RH, Chennareddy C, et al. A comprehensive toolkit of plant cell wall glycan-directed monoclonal antibodies. Plant Physiol. 2010;153(2):514-25.

45. Pattathil S, Avci U, Miller JS, Hahn MG. Immunological approaches to plant cell wall and biomass characterization: glycome profiling. Methods Mol Biol. 2012;908:61-72.

46. DeMartini JD, Pattathil S, Avci U, Szekalski K, Mazumder K, Hahn MG, Wyman CE. Application of monoclonal antibodies to investigate plant cell wall deconstruction for biofuels production. Energy Environ Sci. 2011;4(10):4332-9.

47. Li M, Pattathil S, Hahn MG, Hodge DB. Identification of features associated with plant cell wall recalcitrance to pretreatment by alkaline hydrogen peroxide in diverse bioenergy feedstocks using glycome profiling. RSC Adv. 2014;4(33):17282-92.

48. Deng K, Takasuka TE, Heins R, Cheng X, Bergeman LF, Shi J, Aschenbrener R, Deutsch S, Singh S, Sale KL, et al. Rapid kinetic characterization of glycosyl hydrolases based on oxime derivatization and nanostructure-initiator mass spectrometry (NIMS). ACS Chem Biol. 2014;9(7):1470-9.

49. Deng K, Guenther JM, Gao J, Bowen BP, Tran H, Reyes-Ortiz V, Cheng X, Sathitsuksanoh N, Heins R, Takasuka TE, et al. Development of a high throughput platform for screening glycoside hydrolases based on oxime-NIMS. Front Bioeng Biotechnol. 2015;3:153.

50. Walker JA, Takasuka TE, Deng K, Bianchetti CM, Udell HS, Prom BM, Kim $H$, Adams PD, Northen TR, Fox BG. Multifunctional cellulase catalysis targeted by fusion to different carbohydrate-binding modules. Biotechnol Biofuels. 2015;8:220.

51. Deng K, Takasuka TE, Bianchetti CM, Bergeman LF, Adams PD, Northen $T R$, Fox BG. Use of nanostructure-initiator mass spectrometry to deduce selectivity of reaction in glycoside hydrolases. Front Bioeng Biotechnol. 2015;3:165

52. Takasuka TE, Walker JA, Bergeman LF, Vander Meulen KA, Makino S, Elsen NL, Fox BG. Cell-free translation of biofuel enzymes. Methods Mol Biol. 2014;1118:71-95.

53. Hayashi H, Takehara M, Hattori T, Kimura T, Karita S, Sakka K, Ohmiya K. Nucleotide sequences of two contiguous and highly homologous xylanase genes xynA and xynB and characterization of XynA from Clostridium thermocellum. Appl Microbiol Biotechnol. 1999;51(3):348-57.

54. Fontes CM, Hazlewood GP, Morag E, Hall J, Hirst BH, Gilbert HJ. Evidence for a general role for non-catalytic thermostabilizing domains in xylanases from thermophilic bacteria. Biochem J. 1995;307(Pt 1):151-8.

55. Biely P, Vrsanska M, Tenkanen M, Kluepfel D. Endo-beta-1,4-xylanase families: differences in catalytic properties. J Biotechnol. 1997;57(1-3):151-66.

56. Beaugrand J, Cronier D, Thiebeau P, Schreiber L, Debeire P, Chabbert B. Structure, chemical composition, and xylanase degradation of external layers isolated from developing wheat grain. J Agric Food Chem. 2004;52(23):7108-17.

57. Berrin JG, Juge N. Factors affecting xylanase functionality in the degradation of arabinoxylans. Biotechnol Lett. 2008;30(7):1139-50. 
58. Pollet A, Delcour JA, Courtin CM. Structural determinants of the substrate specificities of xylanases from different glycoside hydrolase families. Crit Rev Biotechnol. 2010;30(3):176-91.

59. Tormo J, Lamed R, Chirino AJ, Morag E, Bayer EA, Shoham Y, Steitz TA. Crystal structure of a bacterial family-lll cellulose-binding domain: a general mechanism for attachment to cellulose. EMBO $J$. 1996;15(21):5739-51.

60. Charnock SJ, Bolam DN, Turkenburg JP, Gilbert HJ, Ferreira LM, Davies $G$ J, Fontes CM. The X6"thermostabilizing" domains of xylanases are carbohydrate-binding modules: structure and biochemistry of the Clostridium thermocellum X6b domain. Biochemistry. 2000;39(17):5013-21.

61. Shin ES, Yang MJ, Jung KH, Kwon EJ, Jung JS, Park SK, Kim J, Yun HD, Kim $\mathrm{H}$. Influence of the transposition of the thermostabilizing domain of Clostridium thermocellum xylanase (XynX) on xylan binding and thermostabilization. Appl Environ Microbiol. 2002;68(7):3496-501.

62. Najmudin S, Pinheiro BA, Prates JA, Gilbert HJ, Romao MJ, Fontes CM. Putting an $\mathrm{N}$-terminal end to the Clostridium thermocellum xylanase Xyn10B story: crystal structure of the CBM22-1-GH10 modules complexed with xylohexaose. J Struct Biol. 2010;172(3):353-62.

63. Czjzek M, Bolam DN, Mosbah A, Allouch J, Fontes CM, Ferreira LM, Bornet O, Zamboni V, Darbon H, Smith NL, et al. The location of the ligand-binding site of carbohydrate-binding modules that have evolved from a common sequence is not conserved. J Biol Chem. 2001;276(51):48580-7.

64. York WS, Harvey LK, Guillen R, Albersheim P, Darvill AG. Structural analysis of tamarind seed xyloglucan oligosaccharides using betagalactosidase digestion and spectroscopic methods. Carbohydr Res. 1993;248:285-301.

65. Li C, Cheng G, Balan V, Kent MS, Ong M, Chundawat SP, Sousa L, Melnichenko YB, Dale BE, Simmons BA, et al. Influence of physico-chemical changes on enzymatic digestibility of ionic liquid and AFEX pretreated corn stover. Bioresour Technol. 2011;102(13):6928-36.

66. Meng X, Ragauskas AJ. Recent advances in understanding the role of cellulose accessibility in enzymatic hydrolysis of lignocellulosic substrates. Curr Opin Biotechnol. 2014;27C:150-8.

67. Demartini JD, Wyman CE. Composition and hydrothermal pretreatment and enzymatic saccharification performance of grasses and legumes from a mixed-species prairie. Biotechnol Biofuels. 2011;4:52.

68. Fry SC, York WS, Albersheim P, Darvill A, Hayashi T, Joseleau J-P, Kato Y, Lorences EP, Maclachlan GA, McNeil M, et al. An unambiguous nomenclature for xyloglucan-derived oligosaccharides. Physiol Plant. 1993;89(1):1-3.

69. York WS, O'Neill MA. Biochemical control of xylan biosynthesis - which end is up? Curr Opin Plant Biol. 2008;11:258-65.

70. Oikawa A, Joshi HJ, Rennie EA, Ebert B, Manisseri C, Heazlewood JL, Scheller HV. An integrative approach to the identification of Arabidopsis and rice genes involved in xylan and secondary wall development. PLOS ONE. 2010:5(11):e15481.

71. Kulkarni AR, Pattathil S, Hahn MG, YorkWS, O'Neill MA. Comparison of arabinoxylan structure in bioenergy and model grasses. Indust Biotechnol. 2012;8:222-9.

72. Pena MJ, Kulkarni AR, Backe J, Boyd M, O'Neill MA, YorkWS. Structural diversity of xylans in the cell walls of monocots. Planta. 2016;244:589-606.

73. Pena MJ, Zhong R, Zhou GK, Richardson EA, O'Neill MA, Darvill AG, York WS, Ye ZH. Arabidopsis irregular xylem8 and irregular xylem9: implications for the complexity of glucuronoxylan biosynthesis. Plant Cell. 2007;19(2):549-63.

74. Andersson SI, Samuelson O, Ishihara M, Shimizu K. Structure of the reducing end-groups in spruce xylan. Carbohydr Res. 1983;111:283-8.

75. Johansson MH, Samuelson O. Reducing end groups in birch xylan and their alkaline degradation. Wood Sci Technol. 1977;11:251-63.

76. Sevcik RS, Mowery RA, Becker C, Chambliss CK. Rapid analysis of carbohydrates in aqueous extracts and hydrolysates of biomass using a carbonate-modified anion-exchange column. J Chromatogr A. 2011:1218(9):1236-43.

77. Scarlata CJ, Hyman DA. Development and validation of a fast high pressure liquid chromatography method for the analysis of lignocellulosic biomass hydrolysis and fermentation products. J Chromatogr A. 2010:1217(14):2082-7.
78. Gupta A, Das SP, Ghosh A, Choudhary R, Das D, Goyal A. Bioethanol production from hemicellulose rich Populus nigra involving recombinant hemicellulases from Clostridium thermocellum. Bioresour Technol. 2014;165:205-13.

79. Ruiz-Matute Al, Hernandez-Hernandez O, Rodriguez-Sanchez S, Sanz ML, Martinez-Castro I. Derivatization of carbohydrates for GC and GC-MS analyses. J Chromatogr B Analyt Technol Biomed Life Sci. 2011;879(17-18):1226-40.

80. Schmidt D, Schuhmacher F, Geissner A, Seeberger PH, Pfrengle F. Automated synthesis of arabinoxylan-oligosaccharides enables characterization of antibodies that recognize plant cell wall glycans. Chemistry. 2015;21(15):5709-13.

81. Kim TW, Chokhawala HA, Nadler DC, Blanch HW, Clark DS. Binding modules alter the activity of chimeric cellulases: effects of biomass pretreatment and enzyme source. Biotechnol Bioeng. 2010;107(4):601-11.

82. Zhang X, Rogowski A, Zhao L, Hahn MG, Avci U, Knox JP, Glibert HJ. Understanding how the complex molecular architecture of mannandegrading hydrolases contributes to plant cell wall degradation. J Biol Chem. 2014;289:2002-12.

83. Poole DM, Durrant AJ, Hazlewood GP, Gilbert HJ. Characterization of hybrid proteins consisting of the catalytic domains of Clostridium and Ruminococcus endoglucanases, fused to Pseudomonas non-catalytic cellulose-binding domains. Biochem J. 1991;279(Pt 3):787-92.

84. Liu W, Zhang XZ, Zhang Z, Zhang YH. Engineering of Clostridium phytofermentans Endoglucanase Cel5A for improved thermostability. Appl Environ Microbiol. 2010;76(14):4914-7.

85. Ye X, Zhu Z, Zhang C, Zhang YH. Fusion of a family 9 cellulose-binding module improves catalytic potential of Clostridium thermocellum cellodextrin phosphorylase on insoluble cellulose. Appl Microbiol Biotechnol. 2011;92(3):551-60.

86. Telke AA, Ghatge SS, Kang SH, Thangapandian S, Lee KW, Shin HD, Um Y, Kim SW. Construction and characterization of chimeric cellulases with enhanced catalytic activity towards insoluble cellulosic substrates. Bioresour Technol. 2012;112:10-7.

87. Cuskin F, Flint JE, Gloster TM, Morland C, Basle A, Henrissat B, Coutinho PM, Strazzulli A, Solovyova AS, Davies GJ, et al. How nature can exploit nonspecific catalytic and carbohydrate binding modules to create enzymatic specificity. Proc Natl Acad Sci USA. 2012;109(51):20889-94.

88. Fujimoto Z, Jackson A, Michikawa M, Maehara T, Momma M, Henrissat B, Gilbert HJ, Kaneko S. The structure of a Streptomyces avermitilis alpha-L-rhamnosidase reveals a novel carbohydrate-binding module CBM67 within the six-domain arrangement. J Biol Chem. 2013;288(17):12376-85.

89. Gao S, You C, Renneckar S, Bao J, Zhang YH. New insights into enzymatic hydrolysis of heterogeneous cellulose by using carbohydratebinding module 3 containing GFP and carbohydrate-binding module 17 containing CFP. Biotechnol Biofuels. 2014;7(1):24.

90. Collins T, Gerday C, Feller G. Xylanases, xylanase families and extremophilic xylanases. FEMS Microbiol Rev. 2005;29(1):3-23.

91. Sabini E, Sulzenbacher G, Dauter M, Dauter Z, Jorgensen PL, Schulein M, Dupont C, Davies GJ, Wilson KS. Catalysis and specificity in enzymatic glycoside hydrolysis: a 2,5B conformation for the glycosyl-enzyme intermediate revealed by the structure of the Bacillus agaradhaerens family 11 xylanase. Chem Biol. 1999;6(7):483-92.

92. Paes G, Berrin JG, Beaugrand J. GH11 xylanases: structure/function/properties relationships and applications. Biotechnol Adv. 2012;30(3):564-92.

93. Natesh R, Bhanumoorthy P, Vithayathil PJ, Sekar K, Ramakumar S, Viswamitra MA. Crystal structure at 1.8 A resolution and proposed amino acid sequence of a thermostable xylanase from Thermoascus aurantiacus. J Mol Biol. 1999;288(5):999-1012.

94. Blommel PG, Martin PA, Seder KD, Wrobel RL, Fox BG. Flexi vector cloning. Methods Mol Biol. 2009;498:55-73.

95. Blommel PG, Becker KJ, Duvnjak P, Fox BG. Enhanced bacterial protein expression during auto-induction obtained by alteration of lac repressor dosage and medium composition. Biotechnol Prog. 2007;23(3):585-98.

96. Klock HE, Lesley SA. The polymerase incomplete primer extension (PIPE) method applied to high-throughput cloning and site-directed mutagenesis. Methods Mol Biol. 2009;498:91-103. 
97. Li C, Knierim B, Manisseri C, Arora R, Scheller HV, Auer M, Vogel KP, Simmons BA, Singh S. Comparison of dilute acid and ionic liquid pretreatment of switchgrass: biomass recalcitrance, delignification and enzymatic saccharification. Bioresour Technol. 2010;101(13):4900-6.

98. Sluiter A, Hames B, Ruiz R, Scarlata C, Sluiter J, Templeton D. NREL analytical procedure LAP-002, determination of structural carbohydrates and lignin in biomass. Golden: National Renewable Energy Laboratory; 2004.

99. Sluiter A, Hames B, Ruiz R, Scarlata C, Sluiter J, Templeton D. LAP-005 NREL analytical procedure, determination of ash in biomass. Golden: National Renewable Energy Laboratory; 2004.

100. Kluepfel D, Vats-Mehta S, Aumont F, Shareck F, Morosoli R. Purification and characterization of a new xylanase (xylanase B) produced by Streptomyces lividans 66. Biochem J. 1990;267(1):45-50.

101. Morais S, Salama-Alber O, Barak Y, Hadar Y, Wilson DB, Lamed R, Shoham $Y$, Bayer EA. Functional association of catalytic and ancillary modules dictates enzymatic activity in glycoside hydrolase family 43 beta-xylosidase. J Biol Chem. 2012;287(12):9213-21.
102. Miller GL. Use of dinitrosalicylic acid reagent for determination of reducing sugar. Anal Chem. 1959;31:426-8.

103. Puhlmann J, Bucheli E, Swain MJ, Dunning N, Albersheim P, Darvill AG, Hahn MG. Generation of monoclonal antibodies against plant cell-wall polysaccharides. I. Characterization of a monoclonal antibody to a terminal alpha-(1 $\rightarrow$ 2)-linked fucosyl-containing epitope. Plant Physiol. 1994;104(2):699-710.

104. Steffan W, Kovac P, Albersheim P, Darvill AG, Hahn MG. Characterization of a monoclonal antibody that recognizes an arabinosylated $(1 \rightarrow 6)$-beta-D-galactan epitope in plant complex carbohydrates. Carbohydr Res. 1995;275(2):295-307.

\section{Submit your next manuscript to BioMed Central and we will help you at every step:}

- We accept pre-submission inquiries

- Our selector tool helps you to find the most relevant journal

- We provide round the clock customer support

- Convenient online submission

- Thorough peer review

- Inclusion in PubMed and all major indexing services

- Maximum visibility for your research

Submit your manuscript at www.biomedcentral com/submit 